\title{
Seepage carbonate mounds in Cenozoic sedimentary sequences from the Las Minas Basin, SE Spain
}

\author{
M. Pozo ${ }^{a, *}$, J . P . C a I v o b ${ }^{\text {, G. Scopelliti }}{ }^{\text {, }}$ L. González-Acebrón ${ }^{\text {d }}$ \\ a Department of Geology and Geochemistry, Faculty of Sciences, Universidad Autónoma de Madrid, 28049, \\ Madrid, Spain \\ ${ }^{b}$ Department of Petrology and Geochemistry, Universidad Complutense, c/ Jose Antonio Novais 2, 28040, Madrid, Spain \\ c Department of Earth and Marine Sciences, Palermo University, Via Archirafi 36, 90123, Palermo, Italy \\ ${ }^{d}$ Department of Stratigraphy, Universidad Complutense, c/ Jose Antonio Novais 2, 28040, Madrid, Spain
}

\section{a b s t r a c t}

A number of carbonate mounds composed of indurate, strongly folded and/or brecciated calcite and dolomite beds occur interstratified in Cenozoic sedimentary sequences from the Las Minas Basin. Part of the fabric of the rock forming the carbonate mounds is composed of laminated to banded dolostone similar to the host rock but showing contrasted lithification. Moreover, the carbonate deposits of the mounds display aggrading neomorphism of dolomite, partial replacement of dolomite by calcite, calcite cementation, and extensive silicifi-cation, locally resulting in box-work fabric. Eight main lithofacies were distinguished in the carbonate mound de-posits. In some lithofacies, chert is present as both microcrystalline to fibro-radial quartz and opal, the latter occurring mainly as cement whereas the former replace the carbonate and infill voids. Yet one of the carbonate mounds shows distinctive petrography and geochemical features thus suggesting a distinctive growth pattern. The carbon isotope compositions of calcite from the mound samples range from -11.56 to $-5.15 \delta \%$ whilst do-lomite is depleted in ${ }^{13} \mathrm{C}$, with values of -12.38 to $3.02 \delta \%$. Oxygen isotopic compositions vary from -9.42 to $-4.64 \delta \%$ for calcite and between -6.68 and $8.19 \delta \%$ for dolomite. Carbonate in the mounds shows significant enrichment in $\mathrm{Co}, \mathrm{Cr}$, Ni and $\mathrm{Pb}$ content, especially in the strongly deformed (F-2-2 lithofacies) and brecciated carbonate (F-4). The carbonate deposits show depletion in REE and $\mathrm{Y}$ in contrast to that determined in lutite. The formation of the carbonate mounds was related to local artesian seepage thermal water flows of moderate to relative high temperatures. Pressure differences between the low permeability host rock and the circulating fluids accounted for dilational fracturing and brecciation of the host sediment packages, which combined with precipitation of new carbonate and silica mineral phases. Locally, some carbonate mounds developed where groundwater intersected the lake floor, this resulting in bedded carbonate deposits composed of organic constituents.

Keywords: Carbonate mounds; Artesian groundwater Seepage; Chert; Cenozoic; SE Spain

1.

\section{Introduction}

The term 'carbonate mound' is commonly used to describe accumulations of mineral carbonate matter characterized by convex-up, domelike geometries (Wilson, 1975; Tucker and Wright, 1990). Recent and fossil carbonate mounds occur in a variety of geological situations including both continental and marine environments, subaerial and subaqueous conditions, and can form in water of any temperature. The composition and fabrics of carbonate mounds are varied, embracing carbonate skeletal and non-skeletal biogenic buildups as well as carbon-ate deposits mainly formed by inorganic processes (Riding, 2002). Mound springs constitute a particular case characterized by freshwater deposits of spring carbonates and/or clastic sediments associated with groundwater discharge (Pentecost, 2005; Linares et al., 2010; Keppel et al., 2011). Moreover, hot spring deposits composed of calcium car-bonate (travertine) and silica (siliceous sinter) lead to spectacular mound structures that witness existence of both recent and fossil geo-thermal systems (Renaut and Jones, 2000, 2003; Pentecost et al., 2003; Jones and Renaut, 2010).

In this paper, a description and genetic interpretation of several carbonate and silica-rich mounds occurring in the central part of the Las Minas Basin, SE Spain is presented. A striking feature is that the mounds are not composed of calcified macro and/or microbiota, as it is usual in tufa and travertine deposits (Pedley, 2009; Brasier, 2011; Fouke, 2011; see discussion on the controversial use of these terms in Jones and Renaut, 2010) but of indurate brecciated, folded and/or faulted host rock, which suggests that their formation was mainly constrained by a combined effect of mechanical and chemical processes.

The carbonate mounds from the Las Minas Basin were first described by Calvo et al. (1995) who compared the mounds to some other occur-rences in Spain and the Basin and Range region in western USA. The

\footnotetext{
* Corresponding author.

E-mail address: manuel.pozo@uam.es (M. Pozo).
} 
authors interpreted the mounds as a result of groundwater seepage at the subsurface linked to geothermal fluids related to volcanism in the basin, a model that should be ruled out according to new observations and mineralogical and geochemical insight.

\subsection{Geological setting}

Las Minas Basin is the largest (ca $160 \mathrm{~km}^{2}$ ) of several Neogene con-tinental intra-mountainous basins located in the external side of the Betic Chain, the so-called Prebetic Zone, in SE Spain (Sanz de Galdeano and Vera, 1992; Van der Beek and Cloeting, 1992) ( Fig. 1). The basins formed as a result of extensional tectonics during the late Miocene (Calvo and Elízaga, 1994; Rodríguez-Pascua et al., 2003).

The Las Minas Basin was filled by an up to $500 \mathrm{~m}$ thick sedimentary succession of lacustrine deposits that unconformably overlie Mesozoic terrigenous, evaporite and carbonate formations, as well as middle Miocene marine carbonate strata. The lowermost deposits cropping out in the Las Minas Basin are composed of resedimented beds from shallow lake carbonate platforms (Elízaga, 1994) and marlstone - limestone cycles representative of shoreface - foreshore subenvironments in the lake basin (Calvo et al., 2000) ( Fig. 2). The carbonate sequences are followed up by a rather monotonous succession of lutite, marlstone (locally paper-shale) and both detrital and chemically-precipitated gypsum beds that reaches up to $145 \mathrm{~m}$ thick in the central part of the basin (Ortí et al., 2014). Abundant authigenic native sulphur and dolomite occur within the marlstone and gypsum beds in some parts of the basin (Lindtke et al., 2011).

The carbonate mounds occur interstratified in the lower part of a package of alternating laminated to banded marlstone and dolostone deposits that overlie the evaporite sequences (Fig. 2). Upwards in the succession, the alternating marlstone and carbonate deposits become progressively enriched in diatomaceous beds (Bellanca et al., 1989) and locally intercalate slump deposits. Elízaga (1994) suggested that the large-scale slump deposits at the uppermost part of the sequence (Fig. 2) were related to seismic activity associated with extrusive, potassium-rich lamproitic volcanism in the region (Fúster et al., 1967; Bellon et al., 1981). Recent work on the radiometric age of the lamproite rocks points to $7.65 \pm 0.02 \mathrm{Ma}$ (Ortí et al., 2014), which is in contrast to a $\mathrm{K} / \mathrm{Ar}$ dating of $5.7 \pm 0.3 \mathrm{Ma}$ obtained by Bellon et al. (1981) but fits better dating (7.2 $\pm 0.4 \mathrm{Ma}$ ) by Nobel et al. (1981) (see also Playà and Gimeno, 2006).

\section{Methods}

After analysis of photogrammetric aerial documents (standard and Google imagery) that allowed the identification of the mound structures

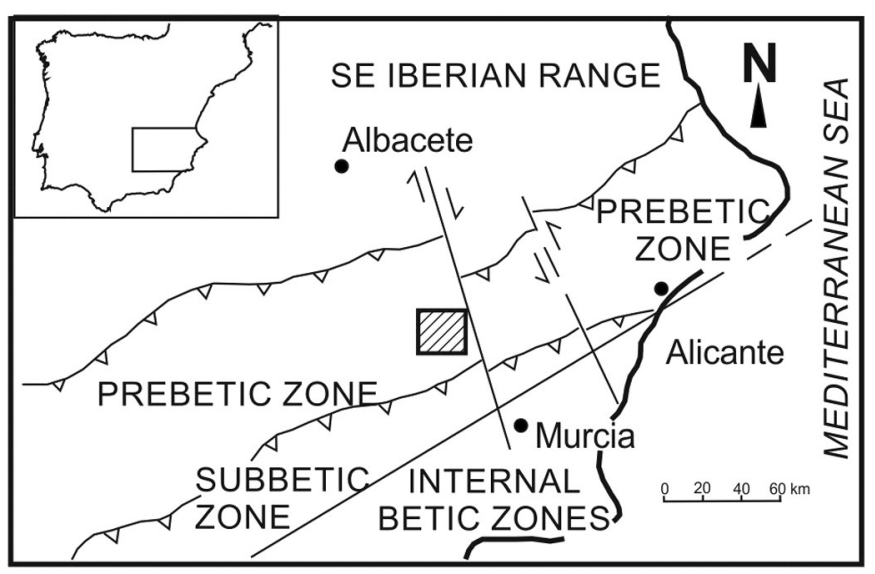

Fig. 1. Location of the study area (boxed) in the Prebetic Zone (southeastern Spain), which is limited by major overthrusts within the Betic Ranges. Note that the study area is limited to the east by a N-S oriented strike-slip fault.

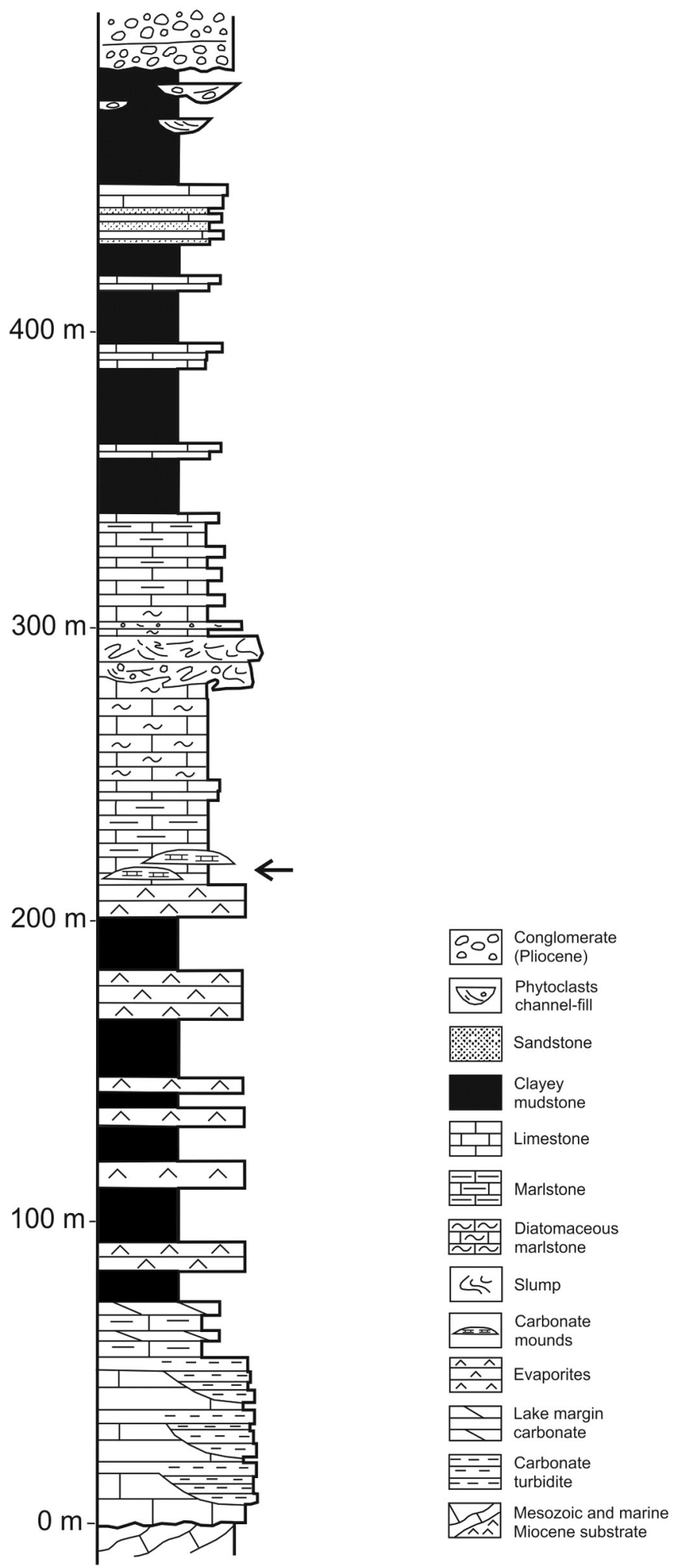

Fig. 2. Composite lithostratigraphic log for the sedimentary infill of the Las Minas Basin (modified from Calvo et al., 2000); arrow indicates location of carbonate mounds.

cropping out in the area, field work was focused on the description and sampling of four main carbonate mounds (see location on Fig. 3). Fifty two samples (Table 1) were collected from several parts of the mounds and the host rock sedimentary sequence.

Rock samples were selected from different parts of the mounds including crest to distal slope transects. Finely polished slabs were 


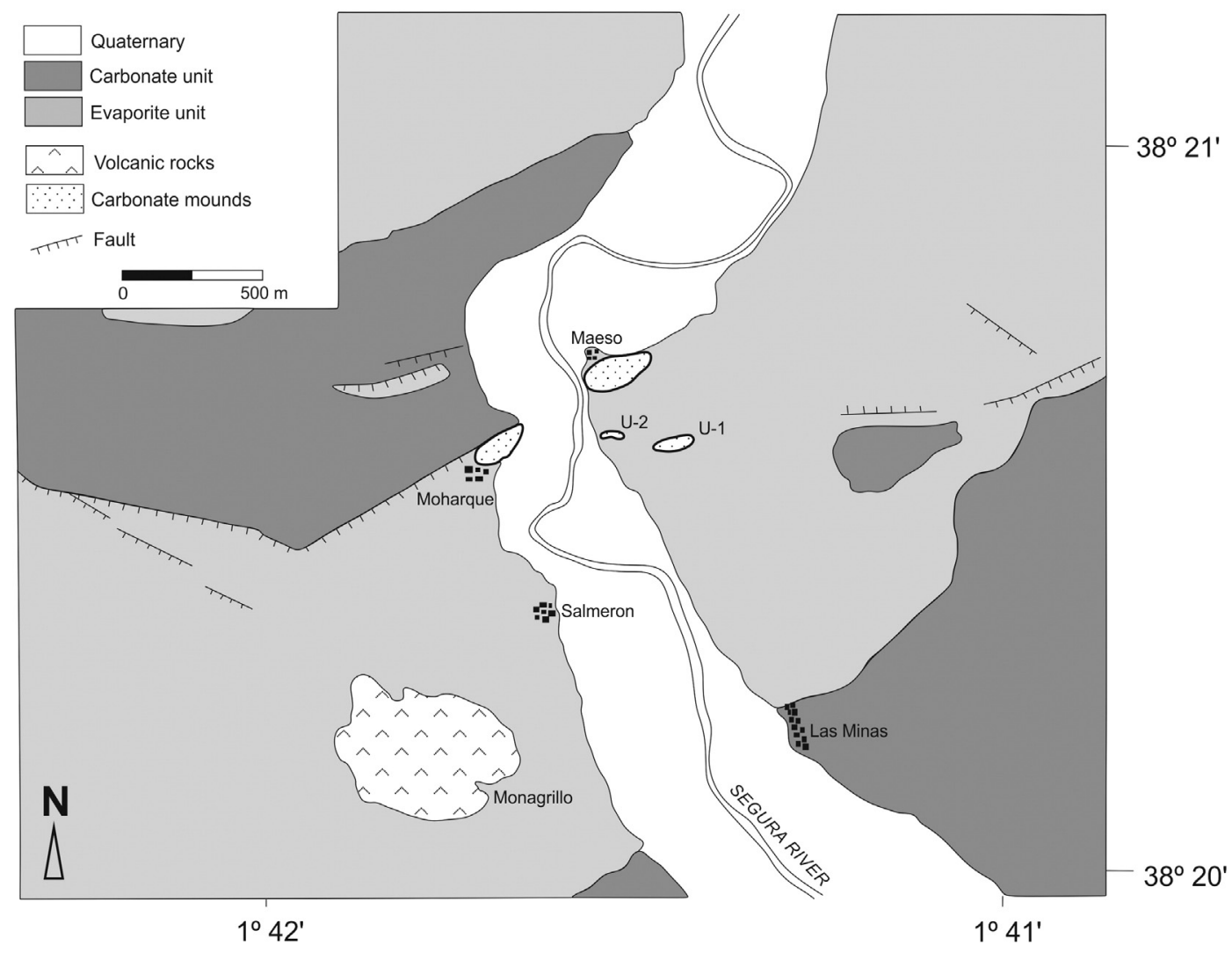

Fig. 3. Geological map of the Las Minas Basin showing the location of the studied carbonate mounds (modified from Ortí et al., 2014).

prepared from all samples. Thin sections were stained for dolomite, ferroan calcite and ferroan dolomite using standard methods (Miller, 1988). Selected samples were examined under a scanning electron microscope (Philips SEM XL-30, FEI, Eindhoven, The Netherlands) after coating with gold (10 $\mathrm{nm}$ thick) in a sputtering chamber. Besides standard petrography methods, the mineralogy for carbonates, chert and clays was determined by X-ray diffraction (XRD) of samples on a Siemens-5000 diffractometer with a scanning speed of $1^{\circ} 2 \theta / \mathrm{min}$ and $\mathrm{Cu}-\mathrm{Ka}$ radiation $(40 \mathrm{kV}, 20 \mathrm{~mA})$. XRD studies were carried out both on randomly oriented samples (bulk sample) and selected clay fraction samples $(\mathrm{b} 2 \mu \mathrm{m})$. Powdered $(\mathrm{b} 63 \mu \mathrm{m})$ whole-rock samples were scanned from $2^{\circ}$ to $65^{\circ} 2 \theta$. Four clay fraction samples were prepared from suspensions oriented on glass slides. Identification of the clay fraction minerals was carried out on oriented air-dried samples, with ethylene glycol solvation, and also after heating at $550{ }^{\circ} \mathrm{C}$. The method of the mineral intensity factors (MIF) was applied to XRD peak intensity ratios normalized to $100 \%$ with calibration constants for the quantitative esti-mation of the mineral content (Chung, 1974). The mole percentage $\mathrm{CaCO}_{3}$ in the dolomite was calculated from the equation of Lumsden (1979) taking into account d-spacings based on Goldsmith and Graf (1958) and Goldsmith et al. (1961), and the ordering degree values estimated according to the $I_{105} / I_{110}$ ratios in dolomite $\left(I_{2.54} \AA / l_{2.40} \AA\right)$ ( Table 2). Eight doubly polished thick sections $(70 \mu \mathrm{m})$ were prepared without any heating and glued to frosted glass with cyanoacrilate for fluid inclu-sions study. After optical petrographic analysis of the sections, selected areas were cut and removed from the glass using acetone to prepare the wafers. The microthermometric study was performed on them using a Linkam THMSG-600 heating and freezing stage. The stage was calibrated with synthetic fluid inclusions, including triple point of $\mathrm{CO}_{2}$, melting point of $\mathrm{H}_{2} \mathrm{O}$, and critical point of $\mathrm{H}_{2} \mathrm{O}$. Melting point of $\mathrm{H}_{2} \mathrm{O}$ standards show that the accuracy for low-temperature measurements are better than $\pm 0.1^{\circ} \mathrm{C}$. Liquid to vapour ratios have been determined in comparison with Sherperd et al. (1985) always at room temperature.
Fluid inclusions measurements were only possible in calcite. Dolomite and quartz did not provide crystal mosaics showing fluid inclusions suitable for microthermometry due to small size of their crystals.

Carbon and oxygen stable isotopes were measured in 45 bulk samples and 12 sub-samples picked up from polished slabs (Table 3). Powders were obtained by using a mechanical micro-sampling drill under a binocular microscope. The measurements were performed at the laboratories of the Interdepartmental Research Service (SIDI) of the Universidad Autónoma de Madrid and at the Dipartimento di Scienze della Terra e del Mare (DISTeM) of the Università degli Studi di Palermo. Carbon dioxide was evolved from each sample at $25^{\circ} \mathrm{C}$ using $100 \% \mathrm{H}_{3} \mathrm{PO}_{4}$. All samples were prepared and analysed at least in duplicate. The analytical precision is generally $\pm 0.10 \%$ for carbon and $\pm 0.15 \%$ for oxygen. Both oxygen and carbon values were initially reported in $\delta$ permil relative to Vienna.Pee.Dee Belemnite (VPDB).

Seven samples of carbonate rock, 2 samples of lutite and one sample of the volcanic lamproite from Cerro del Monagrillo (5)igv e $\mathrm{r}$ e analysed to determine their trace element content and subsequently to evaluate the eventual chemical fingerprint of fluid input into the mounds (Tables 4, 5). The analysed trace elements include $\mathrm{Pb}$, $\mathrm{Sr}, \mathrm{Ba}$, rare earths (from La to Lu plus $\mathrm{Y}$ ) and transition elements $(\mathrm{Cr}$, $\mathrm{Co}, \mathrm{Ni}, \mathrm{V}, \mathrm{Zn}, \mathrm{Cu}, \mathrm{Ti}, \mathrm{Fe}, \mathrm{Mn}$ ). The chemical analysis of major elements (lutites) was performed by means of the MagiX X-ray fluorescence (XRF) spec-trometer of PANanalytical. A varian 220-FS QU-106 atomic absortion (AA) spectrophotometer was used for the determination of sodium. Trace element concentrations were determined by inductively coupled plasma spectrometry (ICP-MS). Samples were analysed after standard procedure by fusion and acid digestion ( $\mathrm{HF}, \mathrm{HNO}_{3}$ and $\mathrm{HCl}$ ).

\subsection{Carbonate mound description}

The carbonate mounds are located in the central part of the Las Minas Basin, 2 km north-west of the village of Las Minas (Fig. 3). The 
Table 1

Carbonate and lutite samples collected from carbonate mound outcrops of Las Minas Basin with indication of their lithology and mineralogical composition.

\begin{tabular}{|c|c|c|c|c|c|c|c|c|c|}
\hline Sample & Lithology & Phyllo & Q & Do & $\mathrm{Ca}$ & Mag & $\mathrm{Ha}$ & Gy & Op \\
\hline \multicolumn{10}{|l|}{ MOHARQUE } \\
\hline MOH-1-1 & Dolostone & & $\mathrm{X}$ & XXX & & $X$ & & & \\
\hline $\mathrm{MOH}-1-2$ & Lutite & $\mathbf{X X X}$ & $\mathrm{X}$ & $\mathrm{XX}$ & & & $\mathrm{X}$ & & \\
\hline $\mathrm{MOH}-1-3$ & Dolostone & & $\mathrm{X}$ & $\mathbf{X X X}$ & & $\mathrm{X}$ & & & \\
\hline $\mathrm{MOH}-1-4$ & Dolostone & & $\mathrm{X}$ & XXX & & $\mathrm{X}$ & & $\mathrm{X}$ & $\mathrm{XX}$ \\
\hline $\mathrm{MOH}-1-5$ & $\begin{array}{l}\text { Silicified } \\
\text { carbonate }\end{array}$ & & $\mathrm{XX}$ & & $\mathbf{X X X}$ & & & & \\
\hline MOH-1-6 & $\begin{array}{l}\text { Silicified } \\
\text { carbonato }\end{array}$ & & $\mathrm{XX}$ & $\mathrm{X}$ & XXX & & & & \\
\hline MOH-1-7 & $\begin{array}{l}\text { Silicified } \\
\text { carbonate }\end{array}$ & & $\mathrm{X}$ & XXX & $X X$ & & & & $\mathrm{XX}$ \\
\hline $\mathrm{MOH}-1-8$ & $\begin{array}{l}\text { Silicified } \\
\text { carbonate }\end{array}$ & & $X X$ & & $\mathrm{XX}$ & & & & $\mathrm{XX}$ \\
\hline MOH-1-11 & Dolostone & $\mathrm{X}$ & $\mathrm{X}$ & $\mathbf{X X X}$ & $\mathrm{X}$ & & & & \\
\hline MOH-1-12 & Dolostone & & $\mathrm{X}$ & $\mathbf{X X X}$ & $X X$ & $\mathrm{X}$ & & & \\
\hline MOH-1-13 & Limestone & $\mathrm{XX}$ & $\mathrm{x}$ & & XXX & & & & \\
\hline MOH-4-1 & Dolostone & & $\mathrm{X}$ & XXX & & $\mathrm{X}$ & & $\mathrm{X}$ & \\
\hline $\mathrm{MOH}-4-2$ & Dolostone & & $\mathrm{X}$ & $\mathbf{X X X}$ & & & & $\mathrm{x}$ & \\
\hline $\mathrm{MOH}-4-3$ & Dolostone & & $\mathrm{X}$ & $\mathbf{X X X}$ & & & & $\mathrm{X}$ & $\mathrm{X}$ \\
\hline TOPMOH-1 & Limestone & & $\mathrm{X}$ & $\mathrm{XX}$ & $\mathbf{X X X}$ & & & & \\
\hline ТОРМОН-2 & $\begin{array}{l}\text { Silicified } \\
\text { carbonate }\end{array}$ & & $\mathrm{XX}$ & & $\mathbf{X X X}$ & & & & \\
\hline ТОРМОН-3 & Limestone & & & $\mathrm{X}$ & XXX & & & & \\
\hline ТОРМОН-4 & Limestone & & $\mathrm{X}$ & $\mathrm{X}$ & XXX & & & & \\
\hline ТОРМОН-5 & Limestone & & & $\mathrm{X}$ & XXX & & & & \\
\hline TOPMOH-6 & Limestone & & $\mathrm{X}$ & $\mathrm{X}$ & XXX & & & & \\
\hline MOH2-1 & Limestone & & & & XXX & & & $X$ & \\
\hline MOH2-2 & $\begin{array}{l}\text { Silicified } \\
\text { carbonate }\end{array}$ & & $\mathrm{XX}$ & & XXX & & & & $\mathrm{X}$ \\
\hline $\mathrm{MOH} 2-3$ & Lutite & $\mathbf{X X X}$ & $X$ & & & & & $\mathrm{X}$ & \\
\hline JABA-1 & Limestone & & $X$ & $\mathbf{X X X}$ & & & & $\mathrm{X}$ & \\
\hline JABA-2 & Limestone & & $\mathrm{X}$ & XXX & & & & $\mathrm{X}$ & \\
\hline JABA-3 & $\begin{array}{l}\text { Silicified } \\
\text { carbonate }\end{array}$ & & $\mathrm{XX}$ & XXX & & & & $\mathrm{X}$ & \\
\hline JABA-4 & Lutite & XXX & $\mathrm{X}$ & & & & & $\mathrm{X}$ & \\
\hline JABA-5 & Lutite & XXX & $\mathrm{X}$ & $\mathrm{X}$ & & & & & \\
\hline JABA-OA & Limestone & & & & $\mathbf{X X X}$ & & & & \\
\hline JABA-OB & Limestone & & & $\mathrm{X}$ & XXX & & & $\mathrm{X}$ & \\
\hline JABA-OC & Dolostone & & & XXX & & $\mathrm{X}$ & & $\mathrm{X}$ & \\
\hline JABA-OD & Dolostone & & & $\mathbf{X X X}$ & & $\mathrm{X}$ & & & \\
\hline \multicolumn{10}{|l|}{$U-1$ and $U-2$} \\
\hline MAE19-4 & Dolostone & & $\mathrm{X}$ & XXX & & & & & \\
\hline MAE19-5 & Dolostone & & $\mathrm{X}$ & $\mathbf{X X X}$ & & & & & \\
\hline MAE19-6 & $\begin{array}{l}\text { Silicified } \\
\text { carbonate }\end{array}$ & & $\mathrm{XX}$ & $\mathbf{X X X}$ & & & & & \\
\hline $\begin{array}{l}\text { MAE-19-3/4 } \\
\text { PEL }\end{array}$ & Limestone & $\mathrm{X}$ & $\mathrm{X}$ & & XXX & & & & \\
\hline MAE20-1 & $\begin{array}{l}\text { Silicified } \\
\text { carbonate }\end{array}$ & & $\mathrm{XX}$ & $\mathrm{XX}$ & XXX & & & & \\
\hline MAE20-3 & Dolomite & & $\mathrm{X}$ & $\mathbf{X X X}$ & $\mathrm{X}$ & & & & \\
\hline MAE20-4 & Dolomite & & $\mathrm{X}$ & $\mathbf{X X X}$ & $\mathrm{X}$ & & & & \\
\hline MAECHERT-1 & $\begin{array}{l}\text { Silicified } \\
\text { carbonate }\end{array}$ & & $\mathrm{XX}$ & $\mathbf{X X X}$ & & & & & $\mathrm{X}$ \\
\hline MAECHERT-2 & Chert & & $\mathrm{XX}$ & $X X$ & & & & & $\mathbf{X X X}$ \\
\hline \multicolumn{10}{|l|}{ MAESO } \\
\hline МOH3-1 & Dolostone & & $\mathrm{x}$ & XXX & $\mathrm{X}$ & & & $\mathrm{X}$ & \\
\hline МOH3-2 & Dolostone & & $\mathrm{x}$ & XXX & $\mathrm{X}$ & & $\mathrm{X}$ & & \\
\hline MOH3-3 & Dolostone & & $\mathrm{x}$ & XXX & & & $\mathrm{X}$ & & \\
\hline MMAESO-01 & Dolostone & & $\mathrm{x}$ & XXX & & & & & \\
\hline MMAESO-02 & Dolostone & & $\mathrm{x}$ & $\mathbf{X X X}$ & $\mathrm{X}$ & & & & \\
\hline MMAESO-03 & Dolostone & & $\mathrm{x}$ & XXX & $\mathrm{X}$ & & & & \\
\hline MMAESO-04 & Dolostone & & $\mathrm{x}$ & XXX & & & & & \\
\hline MMAESO-05 & Dolostone & & & $\mathbf{X X X}$ & & & & & \\
\hline MMAESO-06 & Dolostone & & $\mathrm{x}$ & XXX & $\mathrm{X}$ & & & & \\
\hline MMAESO-07 & Dolostone & & & $\mathbf{X X X}$ & & & & & \\
\hline MMAESO-INY & Dolostone & & & XXX & & & & & \\
\hline
\end{tabular}

XXX (>50\%), XXX (20-50), XX (10-20), X (<10\%).

best exposed mound is located in Moharque, where it is seen as a linear, $\sim 210 \mathrm{~m}$ long, up to $15 \mathrm{~m}$ high, $\sim 30 \mathrm{~m}$ wide ridge (Fig. 4A, B). The height of the mound was measured in the central part of the ridge (Fig. 4C, D).
Table 2

Values of the ordering degree (expressed as $\mathrm{I}_{2.54} / \mathrm{I}_{2.40}$ ) and $\% \mathrm{CaCO}_{3}$ of dolomite in the carbonate mound samples. Lithofacies codes for the carbonate mound deposits are given in the column at right.

\begin{tabular}{|c|c|c|c|}
\hline Sample & $\mathbf{I}_{2.54} / \mathbf{I}_{2.40}$ & $\% \mathrm{CaCO}_{3}$ & Lithofacies \\
\hline MOH-1-11 & 0.510 & 50.01 & $\mathrm{~F} 1$ \\
\hline MOH-4-2 & 0.513 & 50.34 & $\mathrm{~F} 1$ \\
\hline MOH-4-3 & 0.475 & 51.68 & $\mathrm{~F} 1$ \\
\hline MAE1-90-5 & 0.444 & 50.68 & $\mathrm{~F} 1$ \\
\hline $\mathrm{MOH}-1-3$ & 0.470 & 50.01 & F-2-1 \\
\hline JABA-1 & 0.509 & 49.68 & $\mathrm{~F}-2-1$ \\
\hline $\mathrm{MOH}-1-1$ & 0.502 & 50.01 & F-2-2 \\
\hline MOH-1-4-2 & 0.609 & 49.68 & F-2-2 \\
\hline $\mathrm{MOH}-1-4-3$ & 0.540 & 50.01 & $\mathrm{~F}-2-2$ \\
\hline MOH-1-12 & 0.523 & 50.34 & $\mathrm{~F}-2-2$ \\
\hline MOH-4-1 A & 0.357 & 50.01 & F-2-2 \\
\hline $\mathrm{MOH}-4-1 \mathrm{~B}$ & 0.287 & 50.34 & $\mathrm{~F}-2-2$ \\
\hline JABA-2 & 0.492 & 49.34 & $\mathrm{~F}-2-2$ \\
\hline MAE-20-1 & 0.563 & 50.34 & F-2-2 \\
\hline MAE-19-4 & 0.457 & 50.34 & $\mathrm{~F}-4$ \\
\hline MOH-1-7 & 0.402 & 50.01 & $\mathrm{~F}-4$ \\
\hline MAE-20-4 A & 0.384 & 51.34 & $\mathrm{~F}-4$ \\
\hline MAE-20-4B & 0.461 & 51.01 & $\mathrm{~F}-4$ \\
\hline JABA-OC & 0.492 & 50.01 & $\mathrm{~F}-4$ \\
\hline $\mathrm{MOH}-3-1$ & 0.440 & 50.01 & $\mathrm{~F}-7$ \\
\hline MOH-3-2 & 0.414 & 50.68 & F-7 \\
\hline MOH-3-3 & 0.369 & 49.68 & $\mathrm{~F}-7$ \\
\hline MMAESO-1 & 0.394 & 50.68 & F-7 \\
\hline MMAESO-2 & 0.459 & 50.68 & F-7 \\
\hline MMAESO-3 & 0.498 & 50.68 & $\mathrm{~F}-7$ \\
\hline MMAESO-4 & 0.500 & 50.68 & F-7 \\
\hline MMAESO-5 & 0.392 & 50.68 & F-7 \\
\hline MMAESO-6 & 0.310 & 50.34 & $\mathrm{~F}-7$ \\
\hline MMAESO-7 & 0.475 & 50.34 & F-7 \\
\hline MMAESO-INY & 0.677 & 50.01 & F-8 \\
\hline
\end{tabular}

An investigation survey for sulphur deposits carried out by the mining company MINERSA in 1987 showed that a drill-hole placed at the top of the mound passed through a $13.50 \mathrm{~m}$ thick package of silicified lime-stone that overlies well-bedded organic-rich marlstone and carbonate deposits. The mound is included in an alternating marlstone and dolostone succession. The western margin of the mound is bounded by a NE-SW normal fault. The carbonate mound is disrupted by several small, NW-SE oriented normal faults (Fig. 4B). The vertical transition from the carbonate mound deposits to the overlying sequence is gradual but fast and the overlying marlstone beds dip up to $25^{\circ}$ (Fig. 5A). Lateral change of the mound lithofacies into the encasing sed-imentary deposits is not visible at this point.

The transition from host-rock to carbonate mound facies (Fig. 5B) is characterized by fast change of friable alternating thin dolostone and marlstone beds into massive indurate dolostone depicting extensive small-scale folds and fractures. The sequence evolves upwards into a thick package of apparently massive, highly indurate rock, which represents the dominant lithofacies of the ridge. These rocks are mainly brownish grey carbonates and chert, the latter occurring as patches within the mound core. Interestingly, the lowermost part of the Moharque mound shows a carbonate body displaying convex-up geometry, this resulting in deformation of a metre-thick sequence of lutite, marlstone and carbonate beds representative of the host-rock (Fig. $5 \mathrm{~B})$.Lithofacies observation is locally difficult because of rock weathering although some surfaces contribute to highlight subtle differences in the distribution of the carbonate and chert lithofacies. The most typical carbonate facies at outcrop scale consists of strongly deformed and breccia-like fabric, locally silicified thin carbonate beds (Fig. 5C). Abrupt changes from sub-horizontal beds into bundles of vertically oriented carbonate bands are seen in several places across the mound. Moreover, massive vuggy carbonate is a common lithofacies towards the upper part of the mound (Fig. 5D).

Other mound occurrences are located at the left side of the Segura River (Fig. 3). The carbonate mound shown in Fig. 6 (marked $\mathrm{U}-1$ in 
Table 3

Isotopic compositions (expressed as $\delta^{13} \mathrm{C}$ and $\delta^{18} \mathrm{O}$ values) of the carbonate mound samples. Bulk samples are indicated in bold. Lithofacies codes for the carbonate mound deposits are given in the column at right.

\begin{tabular}{|c|c|c|c|}
\hline Samples & $\delta^{13} \mathrm{C}$ & $\delta^{18} 0$ & Lithofacies \\
\hline \multicolumn{4}{|l|}{ Dolomite } \\
\hline МOH-1-11 & -9.80 & 2.15 & $\mathrm{~F}-1$ \\
\hline МOH-4-2 & -7.26 & 6.96 & $\mathrm{~F}-1$ \\
\hline МОН-4-3 & -6.85 & 3.38 & $\mathrm{~F}-1$ \\
\hline MAE-19-5 & -7.52 & 6.01 & F-1 \\
\hline МOH-1-3 & -9.69 & -0.79 & F-2-1 \\
\hline JABA-1 & -10.84 & 1.94 & $\mathrm{~F}-2-1$ \\
\hline МOH-1-1 & -9.50 & -6.21 & F-2-2 \\
\hline MOH 1-1 A & -9.11 & -3.52 & $\mathrm{~F}-2-2$ \\
\hline MOH 1-1B & -8.18 & -1.66 & F-2-2 \\
\hline МОН-1-4 & -11.23 & -6.68 & F-2-2 \\
\hline МOH-1-12 & -12.38 & -5.91 & $\mathrm{~F}-2-2$ \\
\hline MOH 1-12 (23) A & -11.97 & -4.31 & F-2-2 \\
\hline MOH 1-12 (23) B & -9.28 & -2.60 & F-2-2 \\
\hline JABA-2 & -10.87 & -1.45 & $\mathrm{~F}-2-2$ \\
\hline JABA-3 & -10.42 & -5.86 & F-2-2 \\
\hline МОН-4-1а & -10.43 & -6.13 & $\mathrm{~F}-2-2$ \\
\hline МOH-4-1b & -7.89 & -0.55 & F-2-2 \\
\hline $\mathrm{MOH} 1-4$ (2) A & -9.63 & -3.49 & F-2-2 \\
\hline $\mathrm{MOH} 1-4$ (3) A & -10.68 & -5.03 & F-2-2 \\
\hline MOH 1-4 (3) C & -11.14 & -5.80 & F-2-2 \\
\hline MAE-20-1 & -6.29 & -4.64 & $\mathrm{~F}-2-2$ \\
\hline МОН-1-6 & -9.43 & -5.15 & $\mathrm{~F}-4$ \\
\hline МОН-1-7 & -9.25 & 4.74 & F-4 \\
\hline JABA-0C & -9.34 & -4.86 & $\mathrm{~F}-4$ \\
\hline MAE-19-4 & -8.74 & 8.19 & $\mathrm{~F}-4$ \\
\hline MAE-20-4a & -6.48 & 7.94 & F-4 \\
\hline MAE-20-4b & -7.98 & 6.34 & $\mathrm{~F}-4$ \\
\hline моН3-1 & 1.21 & 7.38 & F-7 \\
\hline МОН3-2 & 3.02 & 7.38 & F-7 \\
\hline MOH3-3 & 1.41 & 7.84 & F-7 \\
\hline MMAESO-1 & 1.36 & 7.26 & F-7 \\
\hline MMAESO-2 & 1.94 & 6.96 & F-7 \\
\hline MMAESO-3 & 1.21 & 5.95 & F-7 \\
\hline MMAESO-4 & 1.58 & 7.03 & F-7 \\
\hline MMAESO-5 & 2.01 & 7.16 & F-7 \\
\hline MMAESO-6 & 1.40 & 6.90 & F-7 \\
\hline MMAESO-7 & 1.27 & 6.43 & F-7 \\
\hline MMAESO-INY & 0.49 & -0.67 & F-8 \\
\hline \multicolumn{4}{|l|}{ Calcite } \\
\hline MOH 1-1 A & -9.95 & -6.13 & $\mathrm{~F}-2-2$ \\
\hline MOH 1-1B & -9.38 & -6.00 & F-2-2 \\
\hline $\mathrm{MOH} 1-1 \mathrm{C}$ & -9.29 & -5.12 & $\mathrm{~F}-2-2$ \\
\hline MOH-1-12 & -6.21 & -7.74 & $\mathrm{~F}-2-2$ \\
\hline MOH 1-12 (23) A & -11.86 & -5.73 & F-2-2 \\
\hline MOH 1-12 (23) B & -8.96 & -7.27 & F-2-2 \\
\hline $\mathrm{MOH} 1-4(2) \mathrm{A}$ & -10.76 & -6.66 & $\mathrm{~F}-4$ \\
\hline $\mathrm{MOH} 1-4$ (3) A & -11.16 & -6.57 & $\mathrm{~F}-4$ \\
\hline MOH 1-4 (3) B & -11.13 & -6.35 & $\mathrm{~F}-4$ \\
\hline $\mathrm{MOH} 1-4(3) \mathrm{C}$ & -11.21 & -6.42 & F-4 \\
\hline $\mathrm{MOH} 1-4$ (5) C & -10.74 & -5.84 & $\mathrm{~F}-4$ \\
\hline МOH-1-5 & -8.50 & -8.90 & $\mathrm{~F}-4$ \\
\hline МОН-1-6 & -8.74 & -8.54 & $\mathrm{~F}-4$ \\
\hline MOH 1-6 (17) A & -10.11 & -6.94 & F-4 \\
\hline MOH 1-6 (17) B & -9.58 & -6.16 & $\mathrm{~F}-4$ \\
\hline МOH-1-7 & -5.72 & -5.51 & $\mathrm{~F}-4$ \\
\hline МОН-1-8 & -11.56 & -9.42 & $\mathrm{~F}-4$ \\
\hline JABA-0 A & -5.67 & -8.12 & F-5 \\
\hline JABA-0B & -4.74 & -8.14 & F-5 \\
\hline МОНТОР-1 & -9.63 & -6.93 & $\mathrm{~F}-5$ \\
\hline МОНТОР-3 & -8.53 & -7.80 & $\mathrm{~F}-5$ \\
\hline МОНТОР-4 & -10.94 & -8.73 & F-5 \\
\hline МOHТОР-5 & -10.22 & -8.10 & F-5 \\
\hline МОНТОР-6 & -11.21 & -8.73 & F-5 \\
\hline МOH-1-13 & -5.28 & -8.47 & F-6 \\
\hline MAE-19-3/4 PEL & -4.94 & -8.50 & F-6 \\
\hline
\end{tabular}

Fig. 3) is outstanding as it allows observation of both vertical and lateral relationships with the host rock composed of well-bedded marlstone and dolostone alternations. The outcrop of the carbonate mound is about $40 \mathrm{~m}$ long and up to $6 \mathrm{~m}$ thick. Except for the presence of somewhat more indurate carbonate beds at both bottom and top of the mound lithofacies, the contact between the mound and the enclosing deposits is sharp and can be clearly delineated (Fig. 6). Nor-mal faults can be recognized across the carbonate mound.

Similar carbonate lithofacies occur as a small patch a few tens of metres from the carbonate mound described above (Fig 3 ; the ind urate carbonate patch is labelled U-2). The mound is also interbedded within a marlstone and dolostone sequence. A main outstanding feature is that the carbonate mound is pervasively silicified.

The Maeso mound (see location in Fig. 3) forms a $320 \mathrm{~m}$ long, up to $10 \mathrm{~m}$ high, and $\sim 40 \mathrm{~m}$ wide linear ridge. From west to east, a gradual change from strongly folded indurate carbonate into roughly stratified carbonate beds with intercalated gravel lenses can be recognized. The carbonate displays local staining by metallic ( $\mathrm{Fe}-\mathrm{Mn})$ oxyhydroxides (Fig. 7A). The uppermost part of the mound is formed of well-exposed, decimetre-thick carbonate beds locally displaying gently dip-ping depositional cross beds composed of indurate carbonate breccia fragments (Fig. 7B). In contrast to the other mound occurrences in the area, the Maeso mound does not show evidence of silicification.

\subsection{Petrography and mineralogy}

Six lithofacies (F-1 to F-6) were distinguished in the Moharque, U-1 and $\mathrm{U}-2$ carbonate mounds. The Maeso mound exhibits distinct lithofacies (F7, F8) that will be shown later. The mineralogical composition of the lithofacies is mostly carbonate ( \pm silica phases) with the exception of samples belonging to F-3, which are made-up of clay minerals (Table 1). Values of mole percentage $\mathrm{CaCO}_{3}$ and ordering degree in dolomite from lithofacies F-1, F-2 and F-4 are shown in Table 2 and Fig. 8.

\subsubsection{Massive dolostone ( $F-1)$}

This lithofacies occurs as cm-thick, massive white to yellowish carbonate beds showing occasional fenestral voids and fabric disturbance probably related to burrowing. The texture is characterized by dolomicrite to dolomicrosparite groundmass where the crystal sizes are rarely b5 $\mu \mathrm{m}$. Small bioclasts, i.e. ostracod shells and sponge spic-ules, together with glauconite grains occur scattered within the ground-mass. Besides dolomite the F-1 lithofacies contain small amount of quartz, mainly present as local chalcedonite infilling small voids, and $\mathrm{Fe}$ oxyhydroxides. The order/disorder values of dolomite range from 0.513 to 0.444 . In all cases the carbonate can be characterized as Ca-poor dolomites $\left(\% \mathrm{CaCO}_{3}\right.$ ranging from 51.68 to 50.01$)$ (Table 2, Fig. 8). Some dolostone samples exhibit dark nodules (up to $500 \mu \mathrm{m}$ in size) and/or bands with irregular boundaries (Fig. 9A).

\subsubsection{Laminated dolostone (F-2)}

This lithofacies is characterized by packages of sub-millimetre-thick laminae of dolomicrite, which occur either horizontal (sub-lithofacies F-2-1) (Fig. 9B, C, D) or showing fabrics formed of gently to strongly folded microcrystalline dolomite laminae with local fracturing to smallscale faults (sub-lithofacies F-2-2) (Fig. 9E). In the latter sub-lithofacies, lamination is not well-defined as in F-2-1 and local thicken-ing of the folded laminae is usually recognized (Fig. 9F). Under the mi-croscope the individual laminae show changes in crystal size of the dolomite (from b5 $\mu \mathrm{m}$ to $10 \mu \mathrm{m}$ ) forming couplets of densely to loosely packed crystals (Fig. 9C, D). Mineralogically, the dolomite of lithofacies F-2 shows a large variation of order/disorder values, ranging from 0.609 to 0.444 . In all cases the carbonate can be characterized as Ca-poor dolomites $\left(\% \mathrm{CaCO}_{3}\right.$ ranging from 50.34 to 49.34$)$ (Table 2). The differences in dolomite ordering between lithofacies F-2-1 and F-2-2 suggest the existence of at least two dolomite populations (Fig. 8).

A distinctive generation of dolomite is composed of hypidiotopic mosaics of crystals reaching up to $50 \mu \mathrm{m}$ (dolospar crystals) that usually contain micrite inclusions and show dirty appearance. Crystal size of the dolomite mosaics increases gradually from the dolomicrite masses so 
Table 4

Trace element geochemical composition $(\mu \mathrm{g} / \mathrm{g})$.

\begin{tabular}{|c|c|c|c|c|c|c|c|c|c|c|c|c|c|c|c|c|c|}
\hline Lithofacies & Sample & \multicolumn{2}{|l|}{$\mathrm{Cr}$} & Co & $\mathrm{Ni}$ & $\mathrm{Cu}$ & $\mathrm{Zn}$ & V & \multicolumn{2}{|c|}{$\mathrm{Pb}$} & \multicolumn{2}{|l|}{$\mathrm{Fe}$} & $\mathrm{Mn}$ & \multicolumn{2}{|l|}{$\mathrm{Ti}$} & $\mathrm{Sr}$ & $\mathrm{Ba}$ \\
\hline F-2-1 & МOH1-3 & \multicolumn{2}{|c|}{0.04} & 0.31 & 1.88 & 0.89 & 2.00 & 2.22 & \multicolumn{2}{|c|}{0.63} & 21.39 & \multicolumn{2}{|r|}{29.03} & \multicolumn{2}{|c|}{70.05} & 845.03 & 1.41 \\
\hline F-2-2 & МOH1-1 & \multicolumn{2}{|c|}{0.21} & 0.50 & 2.70 & 1.59 & 3.11 & 3.80 & \multicolumn{2}{|c|}{0.71} & 90.84 & \multicolumn{2}{|r|}{28.48} & \multicolumn{2}{|c|}{153.15} & 687.17 & 1.83 \\
\hline$F-2-2$ & МOH1-4 & \multicolumn{2}{|c|}{0.16} & 3.30 & 25.85 & 0.46 & 1.03 & 1.12 & \multicolumn{2}{|c|}{2.44} & 62.10 & \multicolumn{2}{|r|}{11.84} & 58. & & 889.76 & 3.35 \\
\hline F-3 & МОН-1-2 & 74 & & 12.00 & 29.00 & 46.00 & 95.00 & 130.00 & & & $50,120.00$ & & 540.00 & 5480 & & 265.00 & 208.00 \\
\hline F-3 & МОН-2-3 & 54 & & 22.00 & 36.00 & 38.00 & 73.00 & 99.00 & & & $50,270.00$ & & 590.00 & 595 & & 314.00 & 369.00 \\
\hline $\mathrm{F}-4$ & МOH1-5 & 0. & & 1.63 & 11.39 & 0.20 & 0.57 & 0.23 & & & 6.63 & & 22.17 & 11. & & 276.09 & 1.20 \\
\hline $\mathrm{F}-4$ & МоН1-6 & 0. & & 2.64 & 20.18 & 0.04 & 0.52 & 0.33 & & & 16.77 & & 14.04 & 9.2 & & 366.69 & 2.58 \\
\hline F-5 & MOH-2-1 & 0. & & 0.32 & 3.50 & 0.16 & 0.25 & 0.07 & & & 6.68 & & 13.99 & 4.9 & & 208.08 & 0.99 \\
\hline $\mathrm{F}-7$ & МOH-3-2 & 0. & & 0.63 & 2.38 & 2.29 & 3.03 & 4.11 & & & 24.29 & & 27.42 & 81. & & 403.95 & 97.02 \\
\hline Vrock & МОН-о & 329 & & 21.93 & 66.77 & 9.06 & 49.24 & 78.55 & & & $22,336.22$ & & 281.32 & 10,30 & 89 & 370.08 & 977.16 \\
\hline Lithofacies & Sample & $\mathrm{Y}$ & La & $\mathrm{Ce}$ & $\operatorname{Pr}$ & $\mathrm{Nd}$ & $\mathrm{Sm}$ & $\mathrm{Eu}$ & Gd & $\mathrm{Tb}$ & Dy & Ho & $\mathrm{Er}$ & $\mathrm{Tm}$ & $\mathrm{Yb}$ & $\mathrm{Lu}$ & $\Sigma R E E+Y$ \\
\hline F-2-1 & Мон1-3 & 1.55 & 1.29 & 2.04 & 0.29 & 1.18 & 0.23 & 0.06 & 0.26 & 0.04 & 0.24 & 0.05 & 0.14 & 0.02 & 0.14 & 0.02 & 7.55 \\
\hline F-2-2 & МOH1-1 & 0.90 & 1.11 & 2.07 & 0.24 & 0.94 & 0.22 & 0.05 & 0.18 & 0.02 & 0.17 & 0.03 & 0.09 & 0.01 & 0.10 & 0.01 & 6.14 \\
\hline F-2-2 & МOH1-4 & 0.67 & 0.62 & 2.03 & 0.10 & 0.35 & 0.07 & 0.03 & 0.09 & 0.01 & 0.10 & 0.02 & 0.06 & 0.01 & 0.09 & 0.02 & 4.27 \\
\hline $\mathrm{F}-3$ & Мон1-2 & 16.00 & 24.60 & 46.80 & 5.82 & 22.00 & 4.39 & 0.91 & 3.78 & 0.55 & 3.14 & 0.64 & 1.76 & 0.25 & 1.65 & 0.24 & 132.53 \\
\hline $\mathrm{F}-3$ & МOH2-3 & 15.4 & 24.00 & 41.00 & 5.39 & 19.60 & 3.82 & 0.79 & 3.35 & 0.49 & 2.93 & 0.57 & 1.68 & 0.25 & 1.59 & 0.23 & 121.09 \\
\hline F-4 & МоН1-5 & 0.15 & 0.96 & 0.82 & 0.02 & 0.08 & 0.01 & 0.01 & 0.02 & 0 & 0.01 & 0 & 0.01 & 0 & 0.02 & 0 & 2.11 \\
\hline $\mathrm{F}-4$ & Мон1-6 & 0.48 & 0.90 & 0.25 & 0.04 & 0.11 & 0.03 & 0.01 & 0.05 & 0.01 & 0.10 & 0.03 & 0.06 & 0.01 & 0.09 & 0.01 & 2.18 \\
\hline $\mathrm{F}-7$ & МОН3-2 & 0.64 & 0.60 & 1.14 & 0.14 & 0.59 & 0.15 & 0.03 & 0.13 & 0.02 & 0.11 & 0.02 & 0.06 & 0.01 & 0.06 & 0.01 & 3.71 \\
\hline Vrock & МOH-0 & 29.7 & 99.9 & 258.00 & 41.5 & 181.00 & 36.10 & 5.77 & 19.50 & 1.93 & 7.52 & 1.11 & 2.82 & 0.34 & 1.99 & 0.29 & 687.47 \\
\hline
\end{tabular}

that they can be characterized as a product of aggrading neomorphism (Tucker and Wright, 1990). Moreover, fractures and cracks of the lithofacies F-2-2 are filled up of up to $500 \mu \mathrm{m}$, clean dolomite crystals. Silicification by opal is common in the carbonate; opal cementation is usually followed up by separate chalcedonite quartz cement. Where dolosparite is present, cementation by silica consists of microcrystalline quartz mosaics filling pores that are locally followed by quartz overgrowths.

\subsubsection{Laminated lutite (F-3)}

The lithofacies consists of dark brown laminated lutite showing local umber, iron-rich patches. The lutites occur as $\mathrm{cm}$-thick beds intercalated with laminated dolostone of lithofacies F-2. The composition of the lutite is mainly formed of dioctahedral phyllosilicate $\left(d_{(060)}=\right.$ $1.495 \AA)(80 \%)$ and quartz (6-11\%). The lutite deposits include small dolomite content (4-16\%), some gypsum (b5\%) and halite (b5\%).

Differences in the mineralogical assemblages forming the lutites were observed. These differences are coincident with the location of the lutite deposits. Thus, lutite in contact with strongly deformed carbonates (association 1) shows XRD patterns distinctive from those intercalated with carbonates that were not related to mound growth processes (association 2) (Fig. 10). The main difference is presence of halite and higher dolomite content of the deformed lutites. Regarding clay mineralogy, association 1 shows predominance of illite and Na-saturated smectite with subordinated illite-smectite mixed layer whereas association 2 shows similar content ( 40\%) of illite and smectite but higher presence of mixed-clay minerals and traces of kaolinite. The higher crystallinity of illite in association 1 is outstanding.

The chemical analysis of the lutite supports the mineralogical results. Thus, the high content in $\mathrm{Al}_{2} \mathrm{O}_{3}$-rich silicates (alumina content in the lutite reaches up to $11 \%$ whilst the percentage of $\mathrm{K}_{2} \mathrm{O}$ reaches up to $3 \%$ ), corroborates the predominance of illite and smectite in clay minerals. Likewise, higher content in $\mathrm{K}$ (illite), $\mathrm{Mg}$ (dolomite) and $\mathrm{Na}$ (halite) was determined in the deformed lutites. Fe content of about $5 \%$ deals with phyllosilicates and the occurrence of Fe-oxyhydroxides as observed in hand samples.

The formation of Fe-oxyhydroxides phases seems to be related to re-lease of iron from clay minerals. This is especially clear in samples rep-resentative of association 1 (Fig. 11). Taking into account the low content of dolomite and gypsum in this lithofacies the values of loss on ignition (22-35\%) are mostly indicative of organic matter within the lutite deposits.

\subsubsection{Dolomite-calcite microbreccia (F-4)}

The lithofacies consists of breccia fragments of various sizes composed of both laminated and massive dolomite (Fig. 12A, B). Voids are partly to totally infilled by calcite cement and chert (Fig. 12C, D). Fine crystalline dolomite mosaics are locally replaced by calcite.

The order/disorder values of dolomite range from 0.492 to 0.384 . In all cases the carbonate can be characterized as Ca-poor dolomites

Table 5

Normalized to sample MOH-1-3 trace element contents $(\mu \mathrm{g} / \mathrm{g})$.

\begin{tabular}{|c|c|c|c|c|c|c|c|c|c|c|c|c|c|c|c|c|}
\hline Lithofacies & \multicolumn{2}{|l|}{ Sample } & $\mathrm{Cr}(\mathrm{N})$ & $\mathrm{Co}(\mathrm{N})$ & $\mathrm{Ni}(\mathrm{N})$ & \multicolumn{2}{|c|}{$\mathrm{Cu}(\mathrm{N})$} & $\mathrm{Zn}(\mathrm{N})$ & $\mathrm{V}(\mathrm{N})$ & $\mathrm{Pb}(\mathrm{N})$ & $\mathrm{FeN}()$ & \multicolumn{2}{|c|}{$\operatorname{Mn}(N)$} & $\operatorname{Ti}(\mathrm{N})$ & $\mathrm{Sr}(\mathrm{N})$ & $\mathrm{Ba}(\mathrm{N})$ \\
\hline F-2-2 & \multicolumn{2}{|c|}{ MOH1-1 } & 5.19 & 1.62 & 1.44 & \multicolumn{2}{|c|}{1.79} & 1.55 & 1.71 & 1.12 & 4.25 & \multicolumn{2}{|c|}{0.98} & 2.19 & 0.81 & 1.30 \\
\hline F-2-2 & \multicolumn{2}{|c|}{ МОН1-4 } & 4.02 & 10.64 & 13.75 & \multicolumn{2}{|c|}{0.51} & 0.52 & 0.50 & 3.88 & 2.90 & \multicolumn{2}{|c|}{0.41} & 0.83 & 1.05 & 2.38 \\
\hline F-4 & \multicolumn{2}{|c|}{ МOH1-5 } & 2.89 & 5.25 & 6.06 & \multicolumn{2}{|c|}{0.22} & 0.29 & 0.10 & 2.61 & 0.31 & \multicolumn{2}{|c|}{0.76} & 0.17 & 0.33 & 0.85 \\
\hline F-4 & \multicolumn{2}{|c|}{ МOH1-6 } & 8.59 & 8.52 & 10.73 & \multicolumn{2}{|c|}{0.05} & 0.26 & 0.15 & 3.80 & 0.78 & \multicolumn{2}{|c|}{0.48} & 0.13 & 0.43 & 1.83 \\
\hline F-5 & \multicolumn{2}{|c|}{ МОН-2-1 } & 1.42 & 1.04 & 1.86 & \multicolumn{2}{|c|}{0.18} & 0.12 & 0.03 & 0.82 & 0.31 & \multicolumn{2}{|c|}{0.48} & 0.07 & 0.25 & 0.70 \\
\hline F-7 & \multicolumn{2}{|c|}{ MOH-3-2 } & 4.34 & 2.03 & 1.26 & \multicolumn{2}{|c|}{2.57} & 1.51 & 1.85 & 2.30 & 1.14 & \multicolumn{2}{|c|}{0.94} & 1.16 & 0.48 & 68.81 \\
\hline Lithofacies & Sample & $\mathrm{Y}(\mathrm{N})$ & $\mathrm{La}(\mathrm{N})$ & $\mathrm{Ce}(\mathrm{N})$ & $\operatorname{Pr}(\mathrm{N})$ & $\mathrm{Nd}(\mathrm{N})$ & $\operatorname{Sm}(\mathrm{N})$ & $\mathrm{Eu}(\mathrm{N})$ & $\mathrm{Gd}(\mathrm{N})$ & $\mathrm{Tb}(\mathrm{N})$ & $\operatorname{Dy}(\mathrm{N})$ & $\mathrm{Ho}(\mathrm{N})$ & $\operatorname{Er}(\mathrm{N})$ & $\operatorname{Tm}(\mathrm{N})$ & $\mathrm{Yb}(\mathrm{N})$ & $\operatorname{Lu}(\mathrm{N})$ \\
\hline F-2-2 & MOH1-1 & 0.581 & 0.860 & 1.015 & 0.828 & 0.797 & 0.957 & 0.833 & 0.692 & 0.500 & 0.708 & 0.600 & 0.643 & 0.500 & 0.714 & 0.500 \\
\hline F-2-2 & МOH1-4 & 0.432 & 0.481 & 0.995 & 0.345 & 0.297 & 0.304 & 0.500 & 0.346 & 0.250 & 0.417 & 0.400 & 0.429 & 0.500 & 0.643 & 1.000 \\
\hline F-3 & MOH1-2 & 10.323 & 19.070 & 22.941 & 20.069 & 18.644 & 19.087 & 15.167 & 14.538 & 13.750 & 13.083 & 12.800 & 12.571 & 12.500 & 11.786 & 12.000 \\
\hline F-3 & МOH2-3 & 9.935 & 18.605 & 20.098 & 18.586 & 16.610 & 16.609 & 13.167 & 12.885 & 12.250 & 12.208 & 11.400 & 12.000 & 12.500 & 11.357 & 11.500 \\
\hline F-4 & MOH1-5 & 0.097 & 0.744 & 0.402 & 0.069 & 0.068 & 0.043 & 0.167 & 0.077 & 0.000 & 0.042 & 0.000 & 0.071 & 0.000 & 0.143 & 0.000 \\
\hline $\mathrm{F}-4$ & MOH1-6 & 0.310 & 0.698 & 0.123 & 0.138 & 0.093 & 0.130 & 0.167 & 0.192 & 0.250 & 0.417 & 0.600 & 0.429 & 0.500 & 0.643 & 0.500 \\
\hline F-7 & МОН3-2 & 0.413 & 0.465 & 0.559 & 0.483 & 0.500 & 0.652 & 0.500 & 0.500 & 0.500 & 0.458 & 0.400 & 0.429 & 0.500 & 0.429 & 0.500 \\
\hline
\end{tabular}



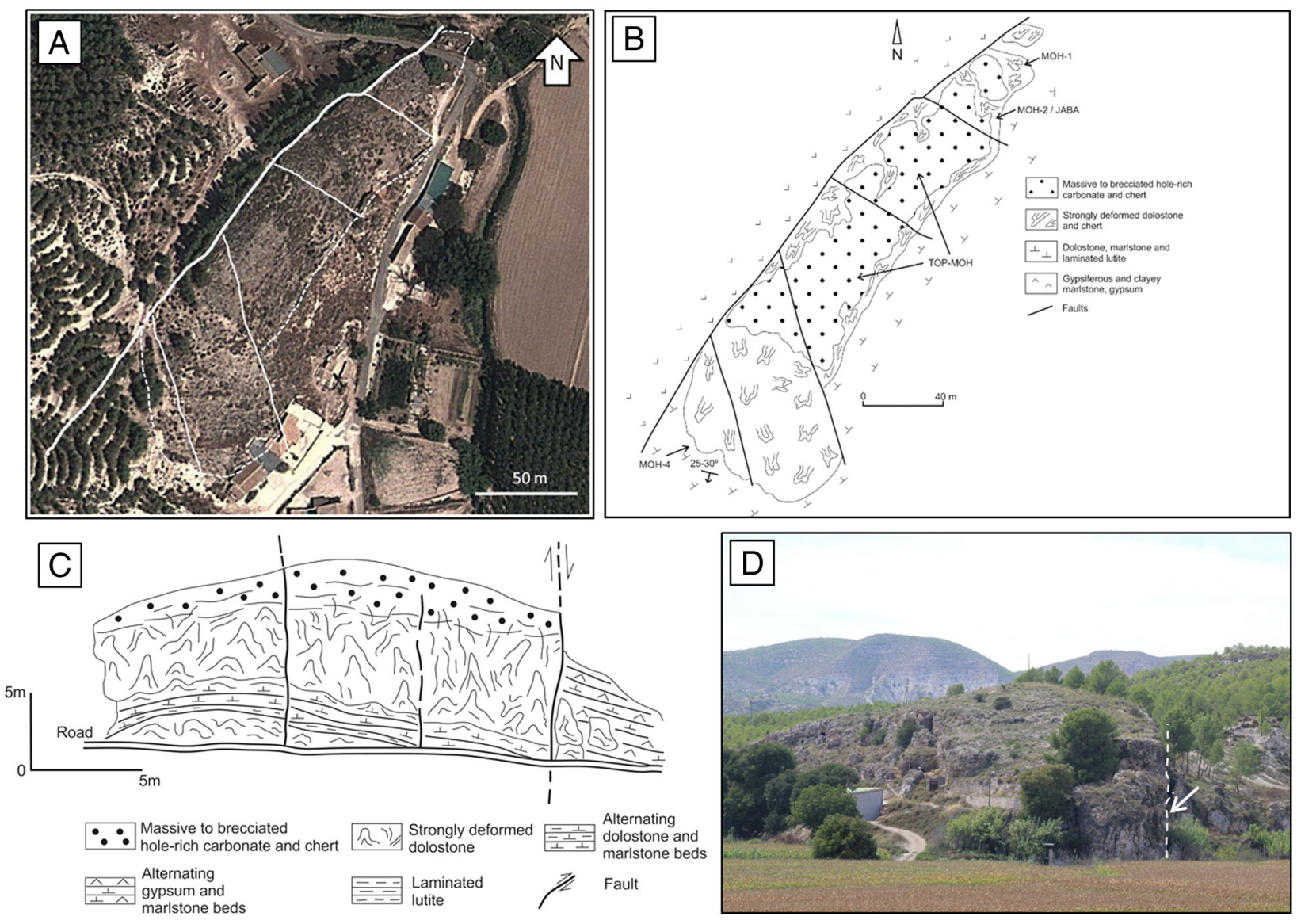

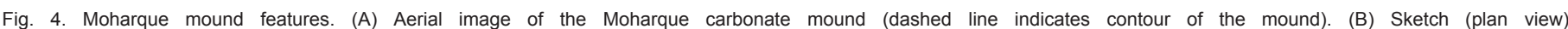

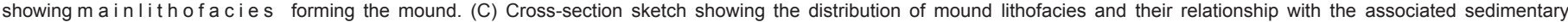
sequences. (D) View from the east of the Moharque mound; note sharp fault contact at right between the carbonate mound and lake evaporite facies.

(\% $\mathrm{CaCO}_{3}$ ranging from 51.34 to 50.01 ) (Table 2, Fig. 8). Chert occurs as both microcrystalline to fibro-radial quartz and opal, the latter occurring mainly as cement whereas the former replace the carbonate and infill voids. Moreover, the breccia fragments show spherulites formed of length slow quartz (quartzine) and mosaics of micro to mesocrystalline quartz replacing the dolomicrite laminae. The pore system of the breccias was tapered by later silicification consisting of length fast quartz (chalcedonite) alternating with opal cement. This feature reveals that silicification processes were largely developed through the formation of lithofacies F-4.

\subsubsection{Breccia to boxwork-like calcite (F-5)}

The lithofacies is characterized by breccias of laminated and deformed fragments of dolomite floating in mosaics of white coarse crystalline calcite and silica cement that occlude centimetre-sized, rectilinear and irregular voids (Fig. 12E). Idiotopic aggregates of colum-nar calcite (Fig. 12F) are largely distributed in the breccias. The replace-ment of laminated dolomicrite fragments by calcite results in mosaics where anhedral calcite crystals range $100-150 \mu \mathrm{m}$ in size. The calcite crystals are usually dirty due to presence of small (up to $20 \mu \mathrm{m}$ ) dolomicrite relics. Other calcite occurrence in this lithofacies consists of fibrousradiaxial coarse crystalline fabrics reaching up $800 \mu \mathrm{m}$ in size. The resulting fabric closely resembles some boxwork dolomites described elsewhere (Swennen et al., 2012; Morrow, 2014). Chert oc-curring as both microcrystalline to fibro-radial quartz and opal is locally observed in this lithofacies. Microcrystalline quartz and quartzine rosettes (slowlength quartz) were precipitated first, affecting both the breccia fragments and columnar calcite. A later silicification process recognized from this lithofacies corresponds to precipitation of chalcedonite (fastlength quartz) and opal lining the pores.

\subsubsection{Fibrous-radial calcite spherulites (F-6)}

This lithofacies occurs locally intercalated with calcite beds of lithofacies 5 from which they are differentiated because of the fibrousradiaxial fabric of the calcite. This results in coalescing, 2-3 m m i n diametre spherulites.

\subsubsection{Dolostones from the Maeso carbonate mound (F-7, F-8)}

The carbonate lithofacies occurring in the Maeso mound show textures that are clearly differentiated from those forming the Moharque, $\mathrm{U}-1$ and U-2 mounds. At least two main carbonate types, all of them composed of dolomite, can be distinguished: F-7 lithofacies, in its turn sub-divided into F-7-1, F-7-2 and F-7-3 sub-lithofacies, and F-8 lithofacies. The latter one corresponds to a carbonate mass that crops out covered by metallic oxyhydroxides (Fig. 7A). The lithofacies is composed of tightly packed mosaic of rhombic to sub-rhombic dolomite crystals ranging 100-150 $\mu \mathrm{m}$. The crystals are zoned exhibiting dark nucleus (Fig. 13A).

In contrast, rock beds forming most of the Maeso mound (Fig. 7B) show a variety of carbonate fabrics (F-7-1, F-7-2, F-7-3) characterized by abundant skeletal and/or organic constituents remains,

i.e., bioclasts, peloids, intraclasts and laminated concretions (Fig. 13B to F). The differences among sub-lithofacies mainly deal with the clastic appearance, the amount of micrite matrix, and the development of lamination and/or banding, which suggests subtle variations in depositional conditions during growth of the carbonate mound.

\subsubsection{Chert}

Quartz and opal occur irregularly distributed in the carbonate deposits. Quartz is present either as micro to mesocrystalline quartz (Fig. 14A) or quartzine and chalcedonite (Fig. 14B). Except for lithofacies 

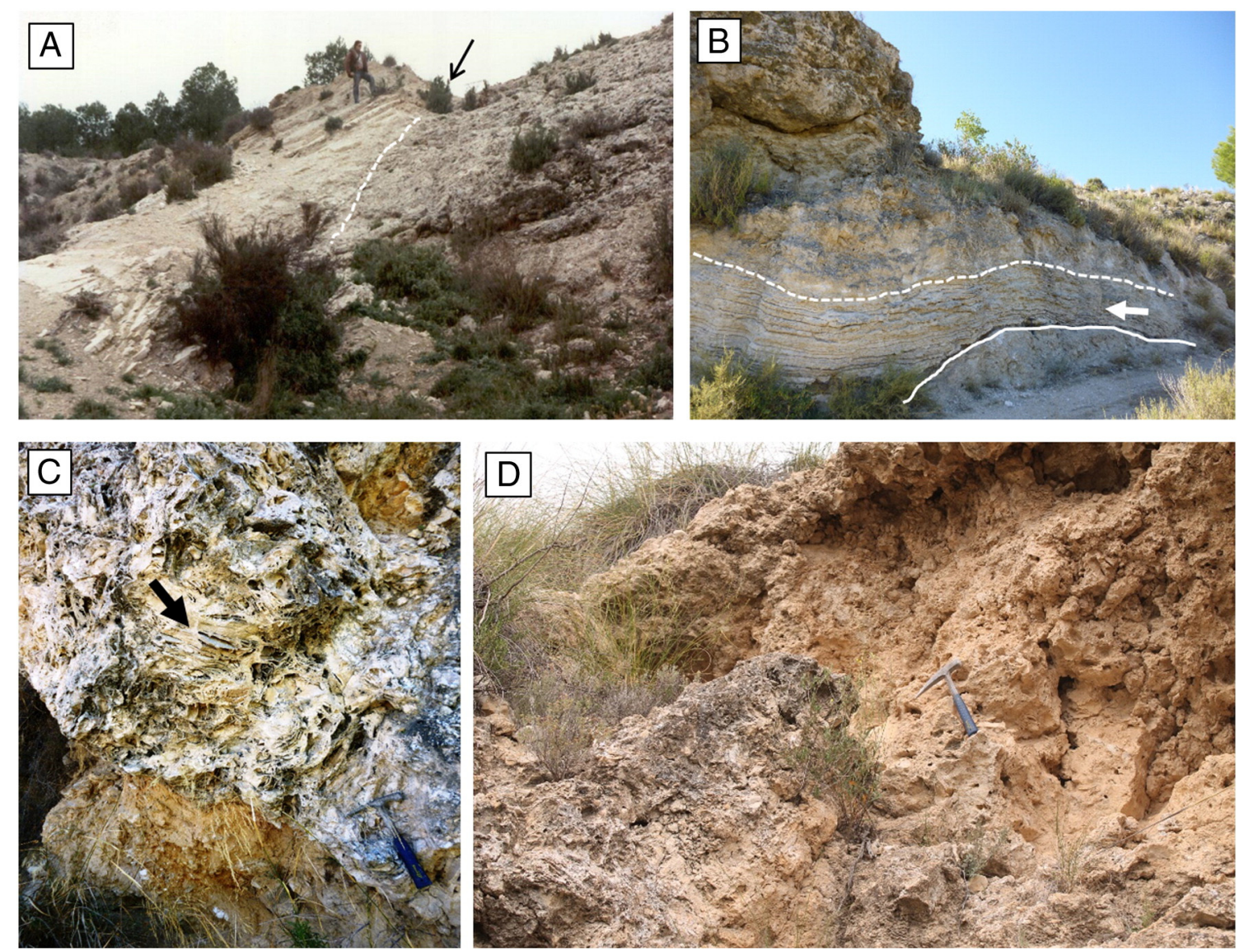

Fig. 5. Moharque mound. (A) Outcrop view of the southwestern part of the mound showing rapid transition (arrow, dashed line) into overlying marlstone beds. (B) Convex up geometry (solid line) of lithified and brecciated carbonate deforming marlstone and lutite deposits (arrow) which in turn change gradually upwards (dashed line) into deformed carbonates. (C) Outcrop view of folded to breccia-like, locally silicified (arrow) thin carbonate beds. (D) Massive carbonate showing abundant medium-size vugs towards the upper part of the ridge.

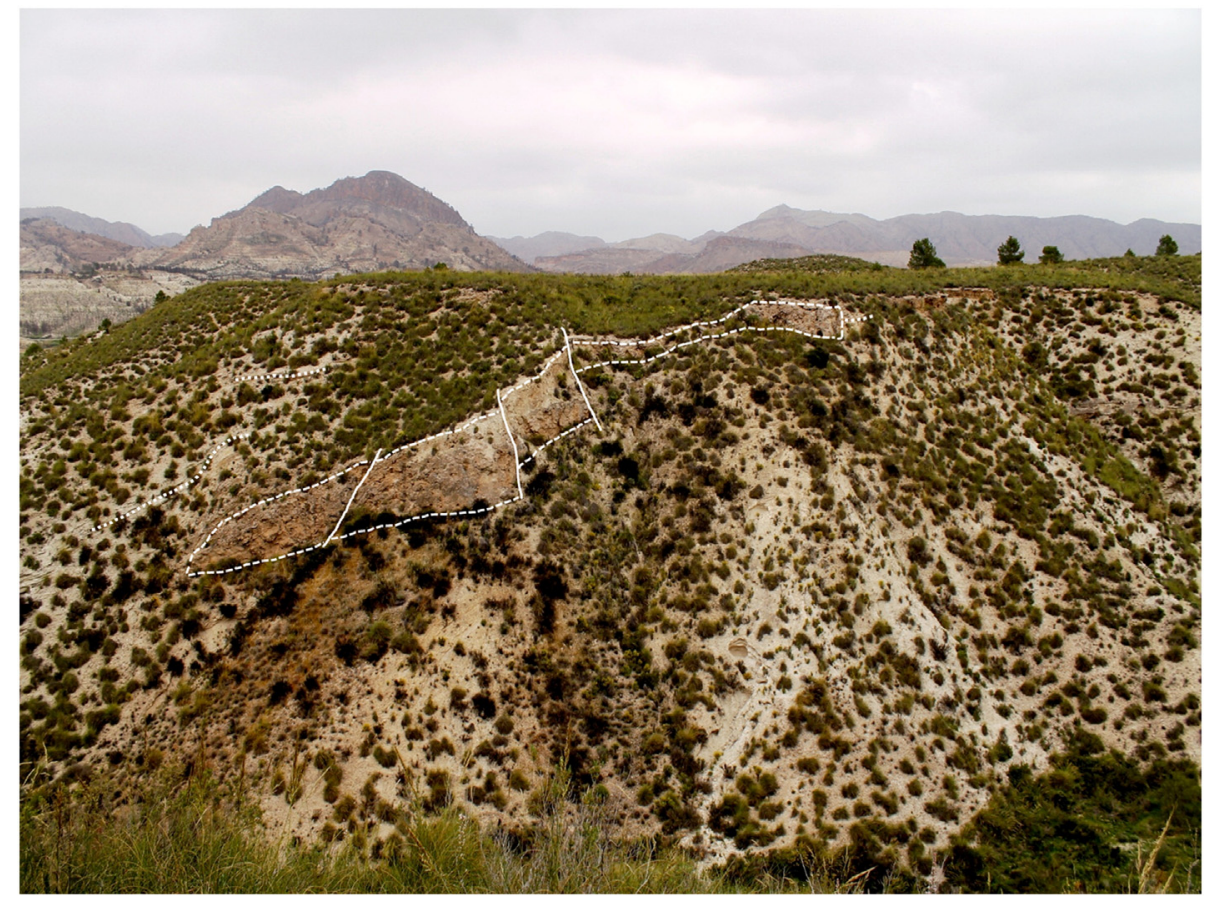

Fig. 6. General view of the carbonate mound U-1 cropping out at the eastern margin of the Segura River (see Fig. 3 for location). Dashed line shows the contact between the mound and the host rock. 

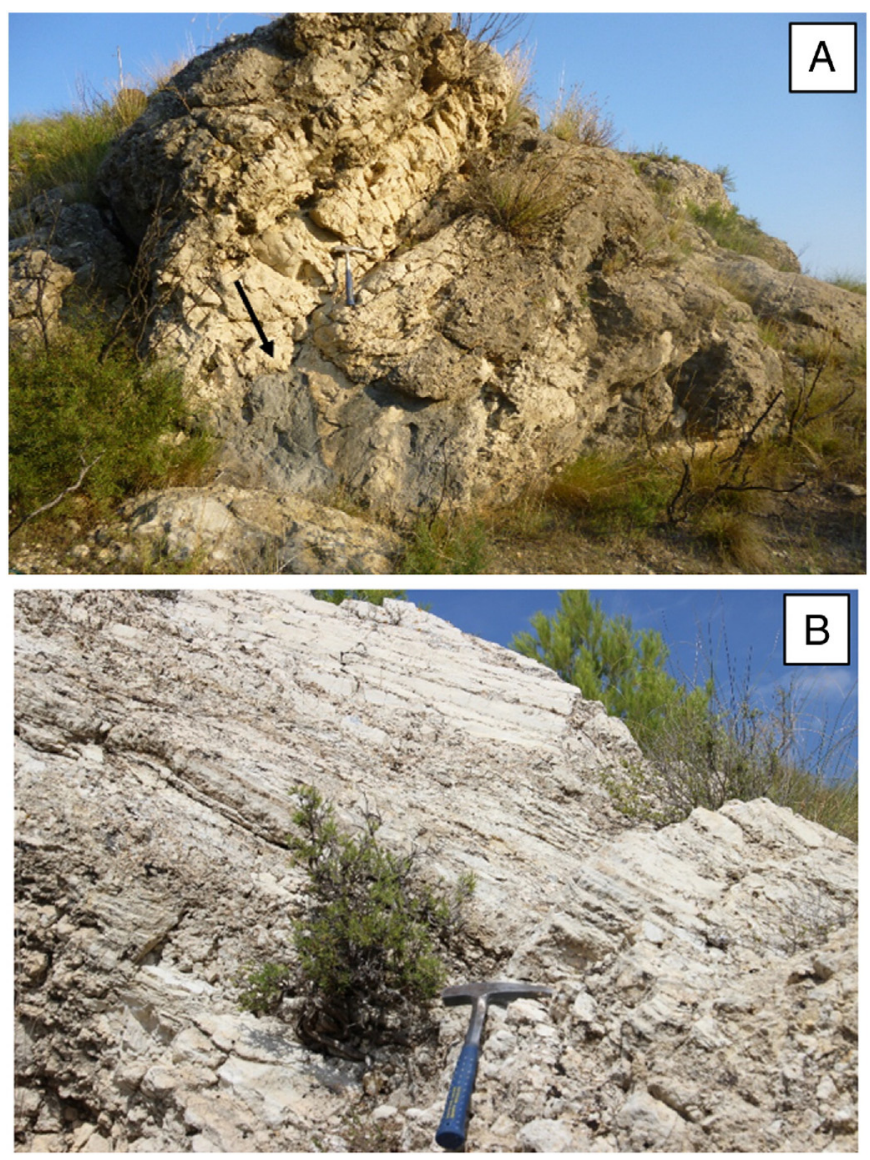

Fig. 7. Maeso mound. (A) Outcrop view of indurate folded carbonate beds; note metallic grey shade due to $\mathrm{Fe}-\mathrm{Mn}$ staining of the rock (arrow) at the base of the outcrop.(B) Indurate carbonate breccias showing gentle depositional cross-bedding (lithofacies F-8).

F-1 and F-5, chert is present in the remaining carbonate lithofacies, which represent most of the total volume of the mounds. Absence or extremely low presence of chert in the Maeso carbonate mound (F-7 and F-8) will be discussed later.

Quartz replaced carbonate and filled fractures, joints and other open porosity throughout the mounds. In contrast, opal occurs mainly as cementing phases usually as thin crusts of fibrous and/or globular opal lining voids (Fig. 14C, D). There is petrographic evidence of the formation of opal-CT that evolved into microcrystalline quartz. Moreover, several silicification stages can be recognized, the main stage having

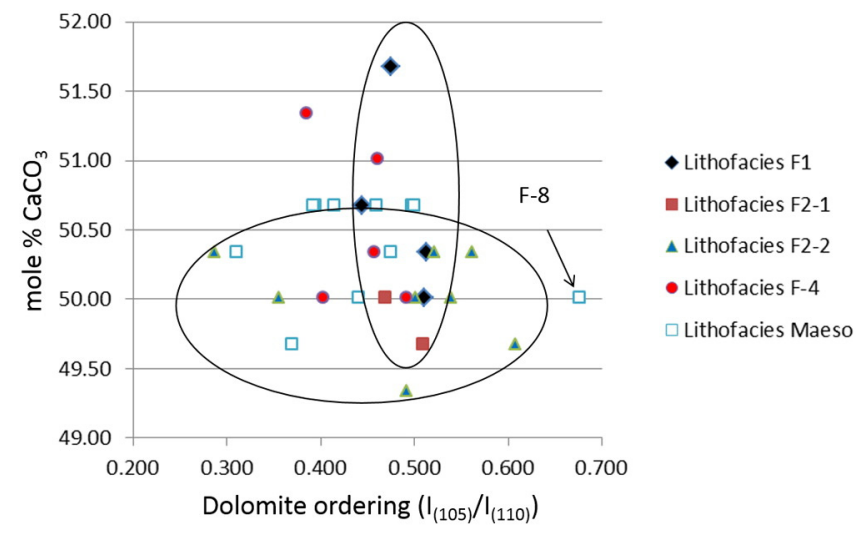

Fig. 8. Diagram showing the distribution of dolomite samples on the basis of dolomite ordering and their $\% \mathrm{CaCO}_{3}$ content; two populations (encircled) are distinguished taken place after aggrading neomorphism of dolomite, partial replace-ment of dolomite by calcite and breccias development.

\section{Geochemistry}

\subsection{Carbon and oxygen isotopes}

Both carbon and oxygen compositions of the carbonate samples col-lected in the mounds are listed in Table 3. The carbon isotope $\left(\delta^{13} \mathrm{C}\right)$ compositions of calcite from the mound samples range from -11.56 to $-4.74 \%$ VPDB whilst dolomite is depleted in ${ }^{13} \mathrm{C}$, with values of $\delta^{13} \mathrm{C}$ ranging -12.38 to $3.02 \%$ VPDB. Oxygen isotopic compositions $\left(\delta^{18} \mathrm{O}\right)$ vary from -9.42 to $-5.12 \%$ VPDB for calcite and between-6.68 and $8.19 \%$ VPDB for dolomite. Distinctively, dolostone samples from the Maeso site show heavy $\delta^{18} \mathrm{O}$ values (averaging $7.53 \%$ VPDB).

In order to understand better and interpret the processes of formation of the mounds, the carbon and oxygen compositions of the carbonate samples were represented in a $\delta^{18} \mathrm{O}-\delta^{13} \mathrm{C}$ cross-plot (Fig. 15). According to their isotope compositions, the samples can be grouped in four main distinctive fields. Samples included in Group A correspond to dolostones showing lithofacies F-7 from the carbonate mound of Cortijo de Maeso. Samples plot closely in the diagram though their cor-relation coefficient is low $\left(R^{2}=0.096\right)$. The range of $\delta^{18} \mathrm{O}$ values does not exceed $2 \%$ VPDB whereas $\delta^{13} \mathrm{C}$ values are slightly more scattered but similar when compared to the other sample groups (Fig. 15). Only one carbonate sample collected in the Maeso mound (F-8) shows an erratic composition $\left(\delta^{13} \mathrm{C}=0.49 \%\right.$ VPDB; $\delta^{18} \mathrm{O}=-0.67 \%$ VPDB $)$ and plots separately.

All carbonate (dolomite) samples characterized as lithofacies F-1 plot in Group B. Samples representative of lithofacies F-2 plot mainly on Group $\mathrm{C}$ although some samples showing features characteristic of this lithofacies have distinct oxygen and carbon compositions; samples characterized as lithofacies F-2-1 have isotope compositions transitional from field B to C. As observed in the cross-plot (Fig. 15), samples includ-ed in these fields are representative of several carbonate lithofacies. Calcite samples representative of lithofacies F-4, $\mathrm{F}-5$ and $\mathrm{F}-6$ are plotted separately showing the most negative $\delta^{18} \mathrm{O}$ values and significant varia-tion of the isotopic carbon.

Thus, the carbonate lithofacies distinguished can be consistently grouped according to their isotope carbon and oxygen compositions. The pattern shows an exception regarding carbonate samples of lithofacies F4, which display significant spread on the cross-plot diagram (Fig. 15)

\subsection{Interpretation of carbon and oxygen isotope compositions}

The dolostones (lithofacies F-7) from the Cortijo de Maeso mound can be interpreted separately as they show quite distinctive isotopic compositions (Fig. 15). The clearly positive oxygen isotope values of this set of carbonate samples suggest precipitation under evaporative conditions. The positive $\delta^{13} \mathrm{C}$ values can be interpreted as a result of degassing, which selectively removes ${ }^{12} \mathrm{C}$ and, to a minor extent, ${ }^{16} \mathrm{O}$ from the water (Chafetz and Guidry, 2003). Only one carbonate sample (MMAESO-INY; Table 1), which consists of dense dolomite mosaics (lithofacies F-8) and interestingly shows metallic staining (Fig. 7A) differs markedly from this pattern. We interpret that the dolostone stained by oxyhydroxides represents carbonate formed within the ground of the lake where no strong evaporative conditions were reached and the degassing effect was negligible. Both conditions are consistent with relatively depleted $\delta^{18} \mathrm{O}$ a n $\mathrm{d} \delta^{13} \mathrm{C}$ values, respectively.

The positive although variable oxygen compositions of the $\mathrm{F}-1$ dolostones indicate precipitation in evaporated waters. The isotopic oxygen values are in the same range of the primary lake facies in which the carbonate mound was built (Ortí et al., 2014). The carbon composition of the $\mathrm{F}-1$ dolostones is characterized by enrichment in light carbon, which can be interpreted as either a consequence of supply of soil 

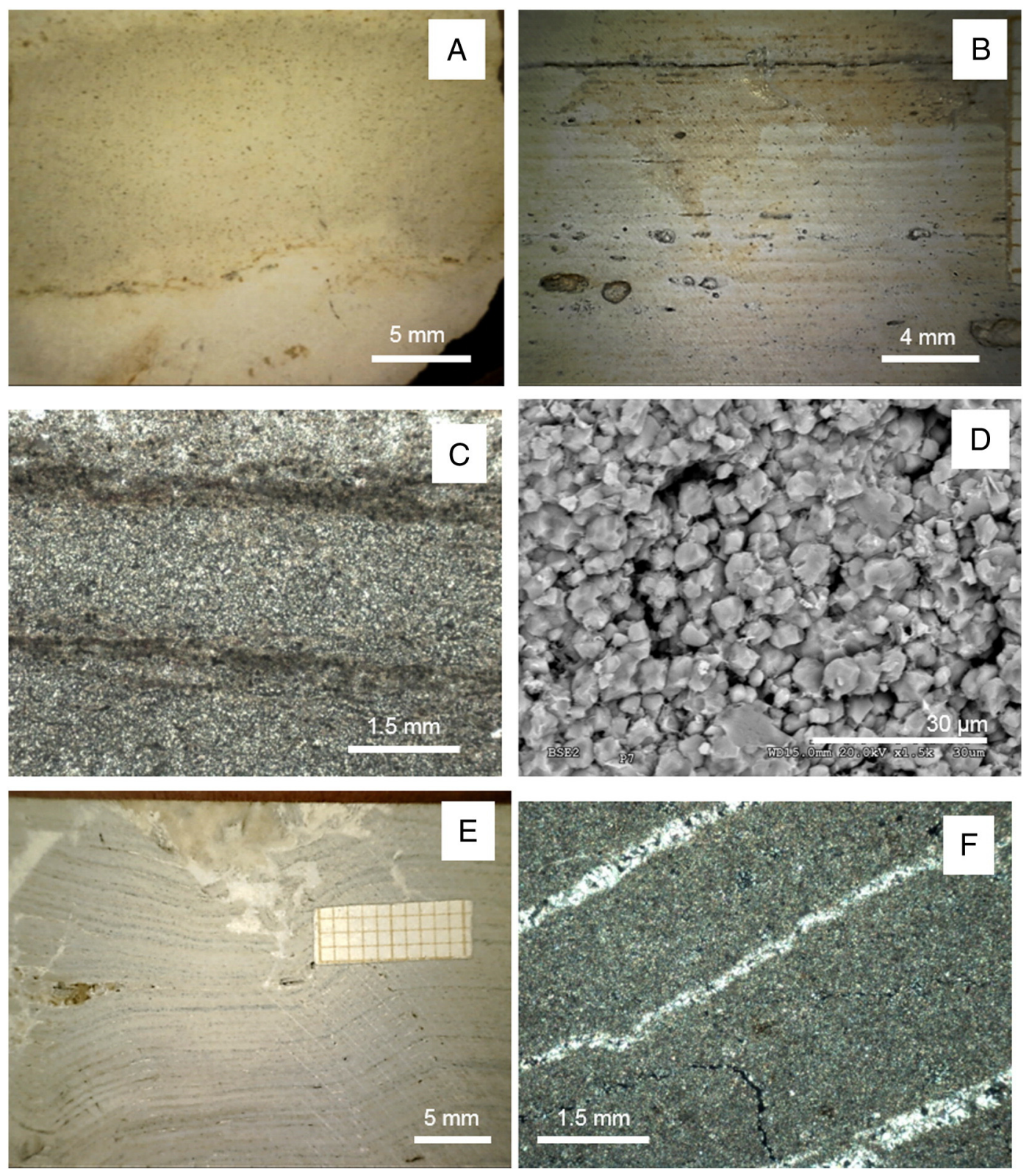

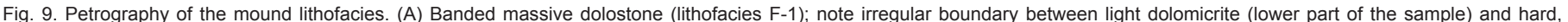

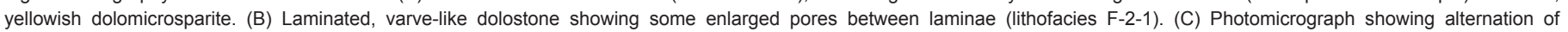

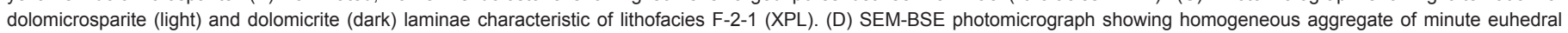

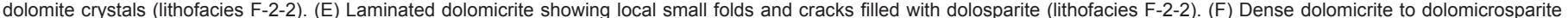
bands separated by coarse crystalline spar dolomite (lithofacies F-2-2) (XPL).

organic carbon to the system (Gonfiantini, 1986; Bellanca et al., 1989) but results from fluid inclusion analysis (see discussion below) strongly can be also due to light $\mathrm{CO}_{2}$ sources related to thermal water sys-tems suggest that calcite cements resulted from precipitation after meteoric (Fouke et al., 2000; Minissale et al., 2002). In the latter case, pro-gressive water during telodiagenetic stages, probably after exhumation of the escape of isotopically light $\mathrm{CO}_{2}$ leads to low $\delta^{13} \mathrm{C} v$ a I u e $\mathrm{s}$ because carbonate mounds.

of isotopic disequilibrium of fluids at the discharge point. This is a reliable explanation for the high content of light carbon in the mound dolomite occurring as F-1 and F-2 lithofacies.

The carbonate samples characteristic of lithofacies F-1, F-2-1 and F- 2-2, in the latter case where isotopic determinations were carried out in the dolomite portion of the sample, show gradual variation from heavy to light oxygen compositions (Fig. 15). We interpret this variation as a result of progressive dilution of thermal water isolated from the evaporative lake environment. The negative oxygen values determined in calcites from samples showing lithofacies F-4, F-5 and F-6 could be matched with dilution and cooling of the hot water involved in the formation of the carbonate mounds. Moreover, texture relationships and

The similitude of negative carbon compositions shown by dolomite samples of groups B and C (Fig. 15) indicates that the source for carbon did not change during the development of the carbonate deposits forming the Moharque, U-1 and U-2 mounds. In contrast, calcites from lithofacies F-4, F-5 and F-6 show wide range of carbon isotopic compo-sitions, which points out to precipitation from meteoric water in an open diagenetic system. This would be consistent with growth of the mounds evolving in a confined system; under these conditions no sig-nificant variation of carbon composition by degassing will be produced (Minissale et al., 2002). The relatively low $\delta^{13} \mathrm{C}$ values of the F-2 dolo-mite can indicate some contribution from thermogenic hydrocarbons (Morrow, 2014). 


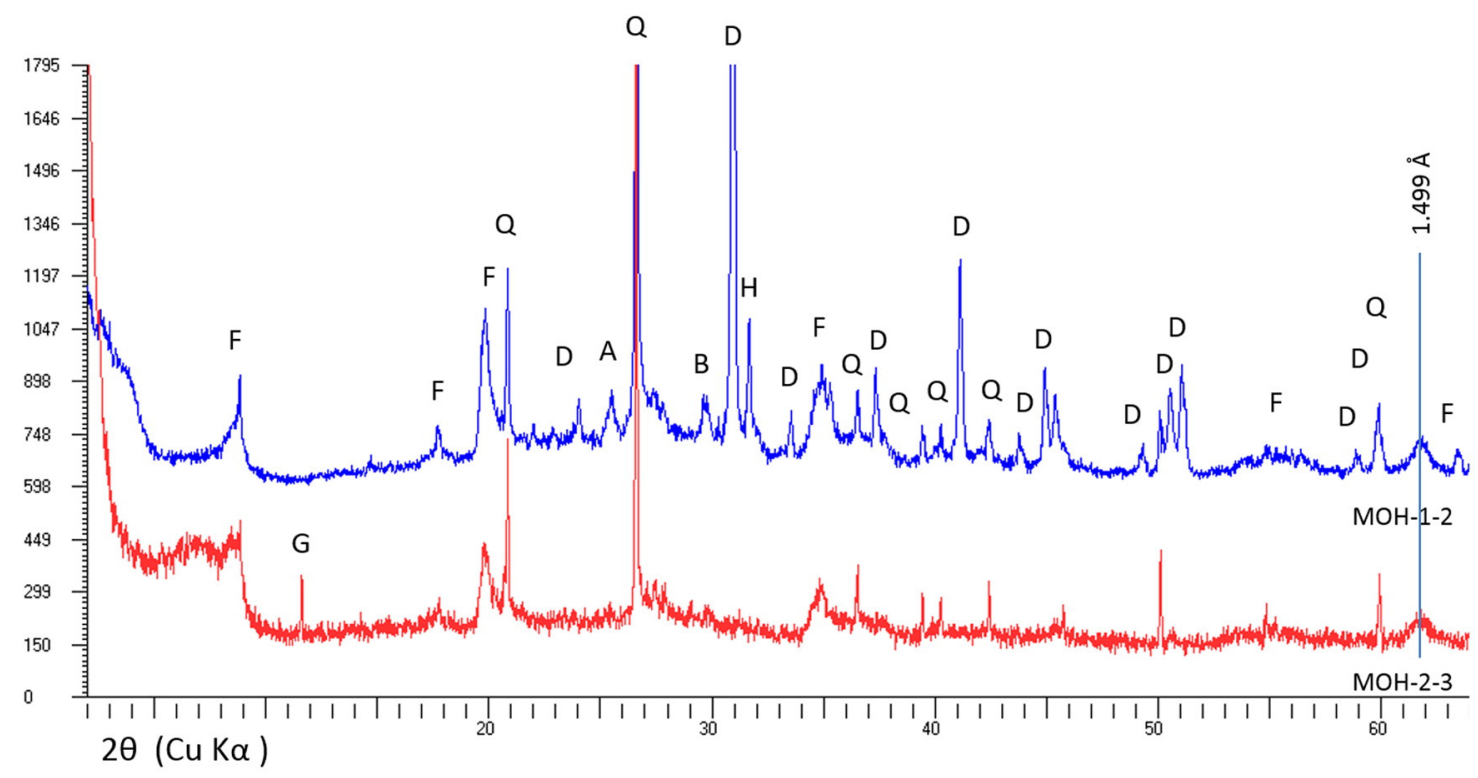

\begin{tabular}{|r|c|c|c|c|c|c|c|c|c|c|c|}
\hline SAMPLE & $\% \mathrm{SiO}_{2}$ & $\% \mathrm{Al}_{2} \mathrm{O}_{3}$ & $\% \mathrm{Fe}_{2} \mathrm{O}_{3}$ & $\% \mathrm{CaO}$ & $\% \mathrm{TiO}_{2}$ & $\% \mathrm{MnO}^{2}$ & $\% \mathrm{~K}_{2} \mathrm{O}$ & $\% \mathrm{MgO}$ & $\% \mathrm{P}_{2} \mathrm{O}_{5}$ & $\% \mathrm{Na}_{2} \mathrm{O}$ & $\% \mathrm{LO}$ \\
\hline MOH1-2 & 40.16 & 11.6 & 5.012 & 7.240 & 0.548 & 0.054 & 3.225 & 8.102 & 0.185 & 1.537 & 22.34 \\
\hline MOH2-3 & 39.83 & 10.75 & 5.027 & 2.229 & 0.595 & 0.027 & 2.630 & 3.252 & 0.133 & 0.256 & 35.27 \\
\hline
\end{tabular}

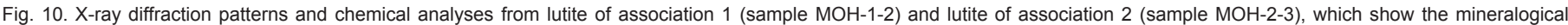

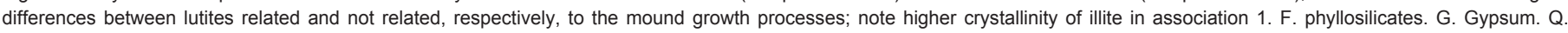
quartz. D. dolomite. A. anhydrite. B. basanite. H. halite.
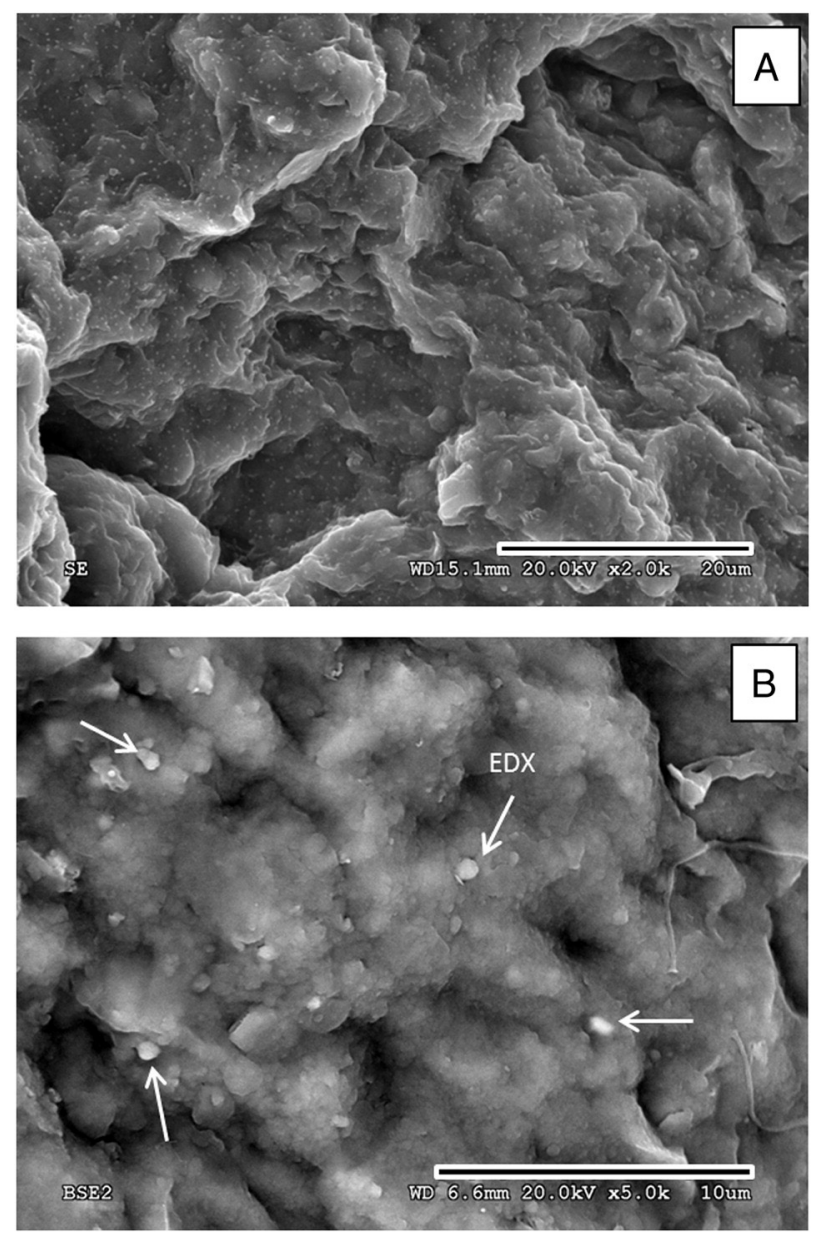

Fig. 11. SEM-BSE view of lutite. (A) Smectite aggregates showing crumpled morphology and low porosity (MOH-1-2). (B) Detail of A showing iron oxides inclusions (arrows). EDX: $40.14 \% \mathrm{Fe}, 38.22 \%$ O, $10.15 \% \mathrm{Si}, \mathrm{b} 5 \% \mathrm{Cl}, \mathrm{Na}, \mathrm{Al}, \mathrm{Mg}, \mathrm{S}, \mathrm{K}, \mathrm{Ca}$

\subsection{Trace element geochemistry}

The content in trace elements of the analysed carbonate, lutite and volcanic rocks is shown in Table 4. The highest concentrations were determined in the lamproite and the lutite samples. The carbonate deposits show lower $\mathrm{Co}, \mathrm{Cr}, \mathrm{Cu}, \mathrm{Pb}, \mathrm{Zn}$ and $\mathrm{V}$ content $(\mathrm{b} 5 \mu \mathrm{g} / \mathrm{g}$ ) whereas concentration of $\mathrm{Fe}, \mathrm{Ni}, \mathrm{Mn}, \mathrm{Sr}$ and $\mathrm{Ti}$ is higher. Barium content is very low (b4 $\mu \mathrm{g} / \mathrm{g}$ ) in the Moharque mound carbonate deposits but high in the Maeso carbonate rocks where Ba content reaches up to $97.02 \mu \mathrm{g} /$ g. This difference in $\mathrm{Ba}$ content was ratified by additional analyses (MMAESO-2, MMAESO-6 and MMAESO-INY samples) (Fig. 16A).

In order to search for the chemical fingerprint of fluid input into the mounds an evaluation of the geochemical enrichment/depletion of trace elements in the carbonate and associated rocks was carried out. Normalization with a non-altered laminated sample ( $\mathrm{MOH}-1-3$; Table 5) was used as a reference for comparison. The abundance of normalized $\mathrm{Mn}$ and $\mathrm{Fe}$ is clearly visible (Fig. 16B). Fe content shows significant depletion in carbonate facies F-4 and F-5, which are calcite-rich, whereas $\mathrm{Mn}$ content shows no variation irrespective of the carbonate facies. Regarding $\mathrm{Ni}, \mathrm{Co}, \mathrm{Cr}$ and $\mathrm{Pb}$ content, the strongly deformed (F-2-2 lithofacies) and brecciated carbonate (F-4) are neatly enriched in these elements. Moreover, detailed analysis of the trace element data (Table 5) points to some chemical differences related to texture. This is clear for sample $\mathrm{MOH}-1-1$, composed of folded dolomite, which is close to the reference carbonate (Fig. 16C). A high positive correlation $\left(R^{2}\right.$ $=0.88-0.98$ ) among $\mathrm{Co}, \mathrm{Ni}$ and $\mathrm{Pb}$ is recognized (Fig. 17A).

Depletion of $\mathrm{Cu}, \mathrm{Zn}, \mathrm{V}, \mathrm{Ti}$ and $\mathrm{Sr}$ is remarkable in carbonate samples of facies F-2, F-4 and F-5, especially where they are calciterich samples (Fig.16D). A very positive correlation among $\mathrm{Cu}, \mathrm{Zn}$ and $\mathrm{V}$ was deter-mined $\left(R^{2}=0.92-0.99\right)$, whilst Ti shows good correlation with $\mathrm{Zn}\left(\mathrm{R}^{2}=0.82\right.$ ) ( Fig. 17B) but moderate correlation with $\mathrm{Fe}$ and $\mathrm{V}$. The $\mathrm{Sr}$ content is very low in calcite-rich samples and shows no correlation with all the aforementioned trace elements. With regard to $\mathrm{REE}$, the higher values correspond to the volcanic lamproite ( $\Sigma \mathrm{REE} N$ $650 \mu \mathrm{g} / \mathrm{g}$ ) and the lutite samples ( $\mathrm{REE}=121-132 \mu \mathrm{g} / \mathrm{g}$ ) whilst $\Sigma$ REE is lower than $10 \mu \mathrm{g} / \mathrm{g}$ in all carbonate facies, in particular those rich in calcite (Table 4). After normalization to the reference sample $\mathrm{MOH}-1-3$, the 

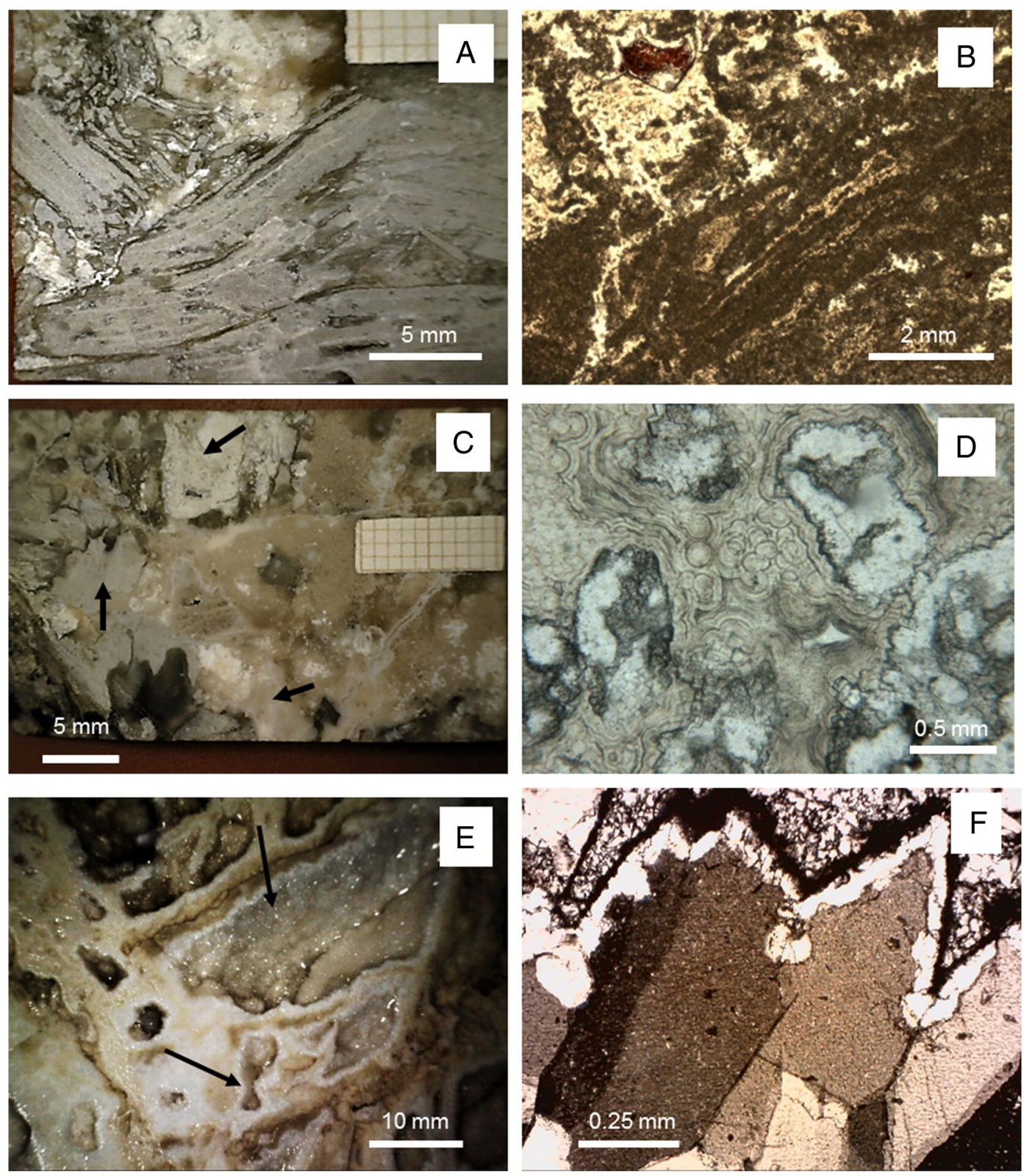

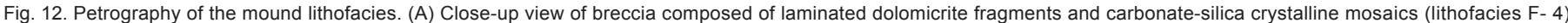

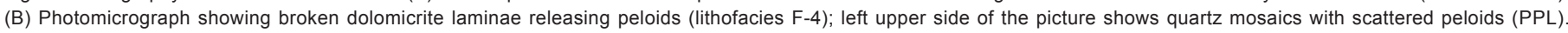

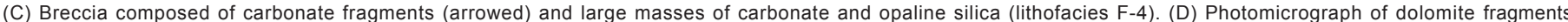

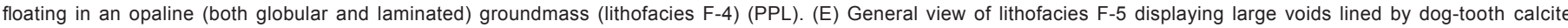

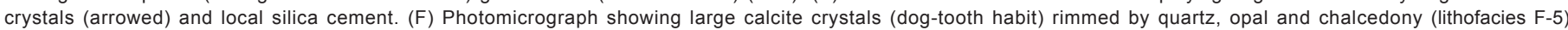
(XPL).

carbonate facies show depletion in REE and $\mathrm{Y}$, in contrast to that deter-mined in lutite (Table 5; Fig. 18A,B).

\subsection{Interpretation of trace element geochemistry}

The breccia texture exhibited by facies F-2-2, F-4 and F-5 suggests input of fluid flows that can also explain dilution and/or mobilization of trace elements. Growth of new mineral phases such as calcite and chert probably resulted in dilution of trace element content as well as mobilization and further leaching of some of these elements, for instance, $\mathrm{Cu}, \mathrm{V}, \mathrm{Ti}, \mathrm{Sr}$ and $\mathrm{Zn}$.

In view of the low mobility of REE, its depletion in carbonate might be also interpreted as a result of the dilution effect caused by growth of new mineral phases (calcite, chert). Enrichment in $\mathrm{Ni}, \mathrm{Co}, \mathrm{Cr}$ and $\mathrm{Pb}$ could be related to input of hydrothermal fluids of magmatic origin.
The volcanic lamproites occurring in the basin can be considered as rep-resentative of the magmatic activity.

\subsection{Fluid inclusions}

The microthermometry of $\mathrm{FI}$ was performed in non-ferroan calcite crystals from lithofacies F-4, F-5 and F-6 that usually limit open voids in the breccias displaying dog-tooth fabrics (Fig. 19A). Calcite crystals usually show dirty nuclei and clean boundaries where occurrence of elongate $\mathrm{FI}$ in the sense of growth is apparent (Fig. 19B), thus providing evidence of their primary nature. FI size ranges from 1 up to $48 \mu \mathrm{m}$ (Table 6) although they are usually very small (b3 $\mu \mathrm{m})$. The FI display irregular morphologies (Fig. 19B) with highly varied liquid to vapour ratios, from $90: 10$ to $60: 40$. This points out to heterogeneous entrapment. Final melting of ice temperatures ( $\left.T_{\text {mice }}\right)$ ranges between 0 and $-3.3^{\circ} \mathrm{C}$ 

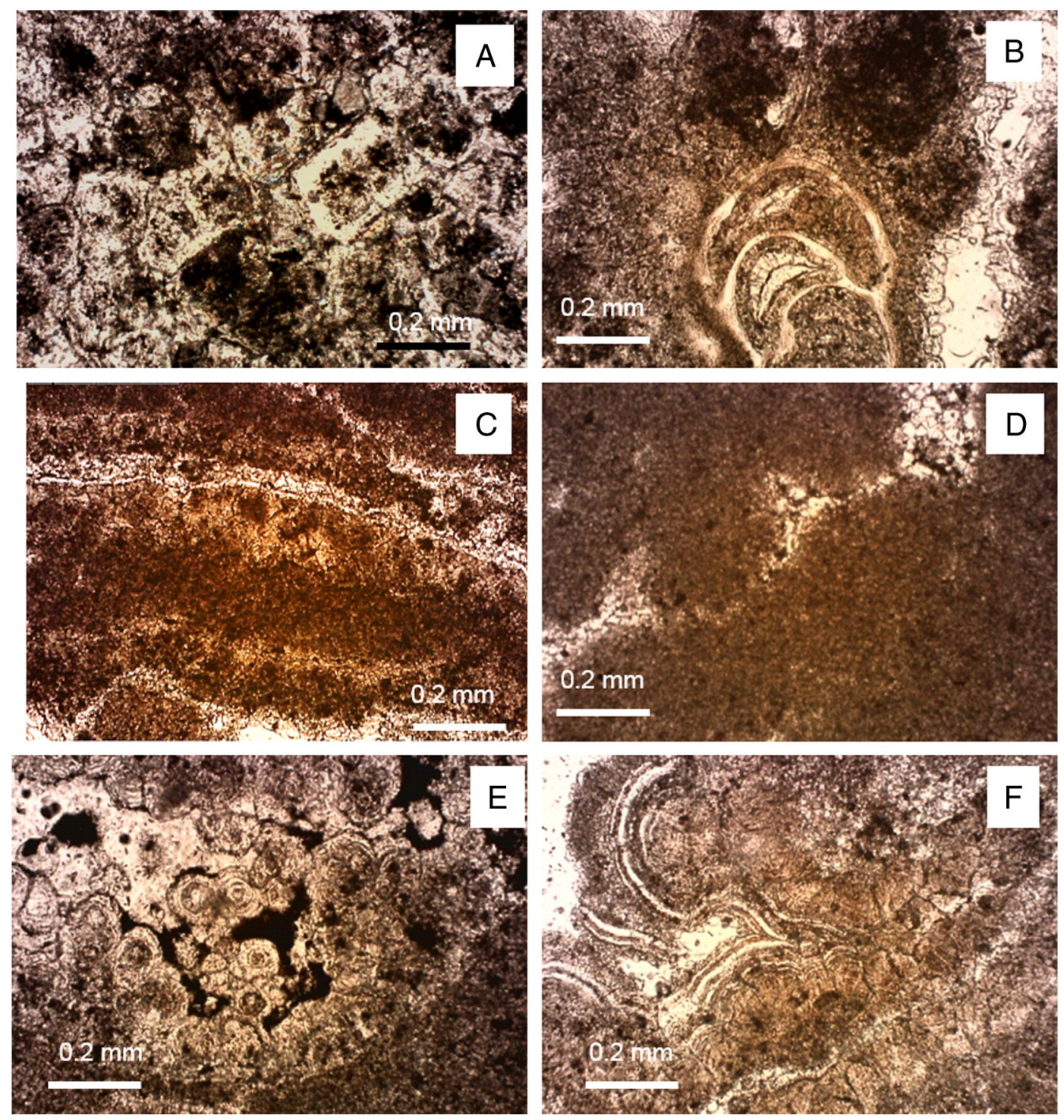

Fig. 13. Petrography of the Maeso mound lithofacies. (A) Photomicrograph of planar-idiotopic to subidiotopic dolomite fabric displaying dark nucleus and limpid outer zones (lithofacies F8) (PPL). (B) Dolostone showing preserved grain-supported peloids and gastropod shells. The channel void shows a pore-lining of dolomite (lithofacies F-7-1) (PPL). (C) Banded

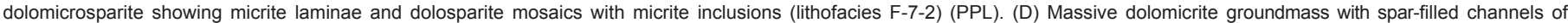

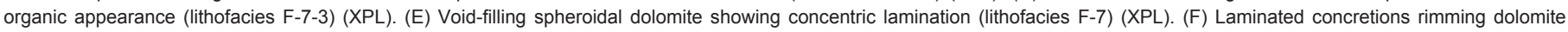
mosaics (lithofacies F-7) (PPL).

(Table 6), the values close to $0{ }^{\circ} \mathrm{C}$ being most abundant; a minor population between -2.5 and $-3.3^{\circ} \mathrm{C}$ is related to the $\mathrm{FI}$ occurring close to the dirty nuclei of the calcite crystals (Fig. 19A and C). FI were cooled until liquid nitrogen temperatures but no other melting events different than ice were recorded. Eutectic temperatures are around $-21{ }^{\circ} \mathrm{C}$ pointing to water- $\mathrm{NaCl}$ bearing system. Calculated salinities are between fresh water and 5.41\% w (NaCl-eq) (Table 6) (Bodnar, 1993).

The freshwater entrapment and the variable liquid to vapour ratios of the $\mathrm{FI}$, the negative oxygen isotope values of calcite from lithofacies F-5 and F-6 (Fig. 15), and the textural evidence of this mineral as a last precipitate of the diagenetic sequence, altogether point to heterogeneous entrapment under vadose conditions at temperatures lower than $50{ }^{\circ} \mathrm{C}$ (Goldstein and Reynolds, 1994). This strongly suggests that the calcite was formed during meteoric telodiagenesis.

\subsection{Formation of the carbonate mounds}

The studied carbonate mounds occur discontinuous within a monotonous lacustrine succession. On the basis of field observation it seems that the scattered mounds were formed at the same stratigraphic level coincident with the deposition of carbonate, mainly dolostone and marlstone deposits overlying evaporite gypsum and sulphur (Calvo and Elízaga, 1994; Ortí et al., 2014) ( Figs. 2, 3). A close relationship between the mounds and some major faults in the basin is also recognized (Fig. 3).

The convex-up morphology combined with the petrographic features shown by the carbonate mounds suggest a formation model where hydraulic discharge of groundwater is considered to have been the main triggering mechanism. Yet moderate to high temperature of the groundwater must be constrained in order to explain the mineralogy, facies and fabrics of the carbonate deposits. A distinction between two main mound types must be addressed according to the sedimentary features displayed by the carbonate deposits of the Maeso mound and those from the Moharque, $\mathrm{U}-1$ and $\mathrm{U}-2$ mounds. The distinction deals with the groundwater flow pattern and the locations of the discharge points in the lake basin (Fig. 20). We interpret the carbonate mounds of the Las Minas Basin as thermal spring deposits related to me-dial fissures. However, only one of the 4 studied mounds, the Maeso 


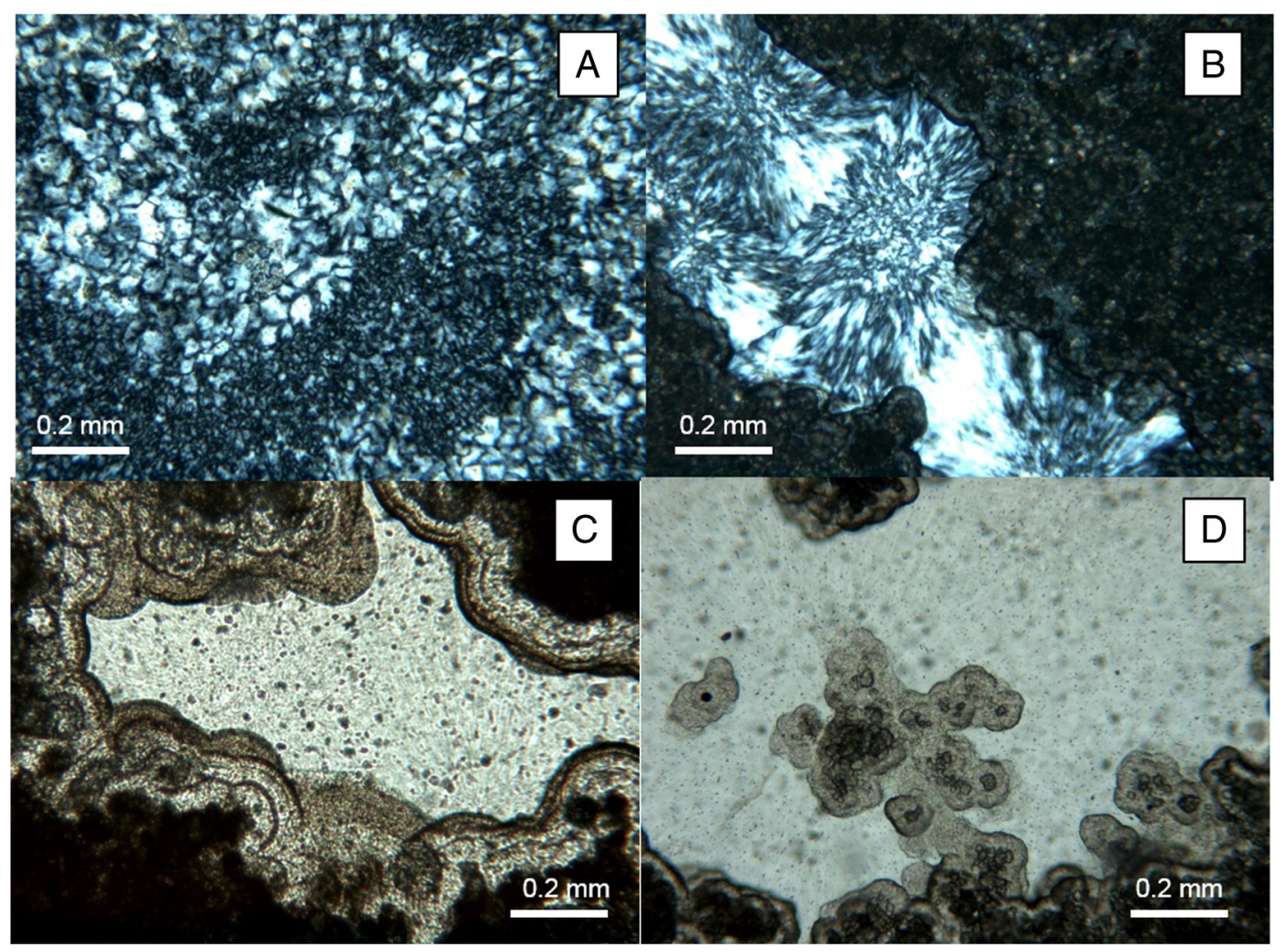

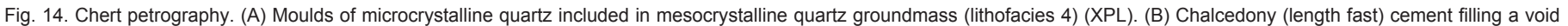

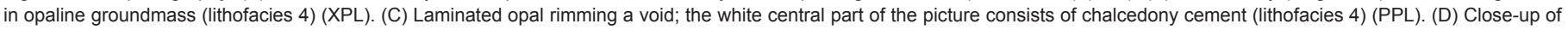
globular opal with dark cores surrounded by chalcedony cement (lithofacies 4) (PPL).

one, matches springs where thermal waters rise to the land surface, i.e. the lake floor. The rest of the mounds represent subsurface discharge, rather than interaction with the Las Minas lake water.

The main lithofacies (F-1 to F-6) observed in the Moharque, U-1, $\mathrm{U}-2$, and locally in the Maeso mound show two outstanding features in common: a) the host laminated dolomicrite is present as a major fabric constituent in the mound lithofacies, except in the breccias-like lithofacies $\mathrm{F}-5$, and b) no organic remains, e.g. bioclasts, plants, bacterial and/or microbial structures, are clearly identified within the carbonate lithofacies. The latter feature is in contrast with that observed in lithofacies F-7, which forms most of the Maeso mound.
A sequential order of precipitation can be established on the basis of field relations, petrography, mineralogical composition and isotope sys-tematics. Thus, in the Moharque mound (Fig. 4B, C) the carbonate de-posits showing lithofacies F-1 changes upwards into F-2 lithofacies and this in its turn changes into F-4. This stratigraphic relationship strongly suggests that the process progressed from bottom to top or from the inner to the outer part of the mound. This ran in parallel to the sequential order of mineral precipitation and their correlative tex-tures and/or fabrics that can be summarized as follows:

\footnotetext{
- Host rock-dolomicrite (lithofacies F-1 and F-2-1) and lutite (lithofacies F-3)
}

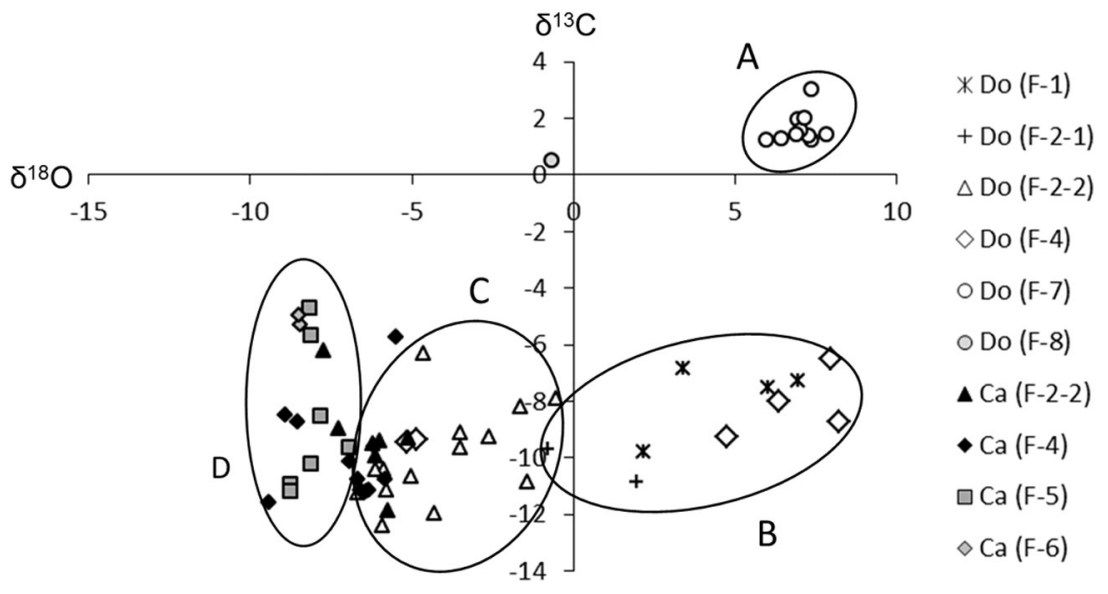

Fig. 15. $\delta^{13} \mathrm{C}-\delta^{18} \mathrm{O}$ cross-plot diagram representing the distribution of the carbonate lithofacies according to their isotopic composition. Four main groups of carbonate samples (encircled) can be differentiated; one sample corresponding to lithofacies F-8 plots clearly separated. 

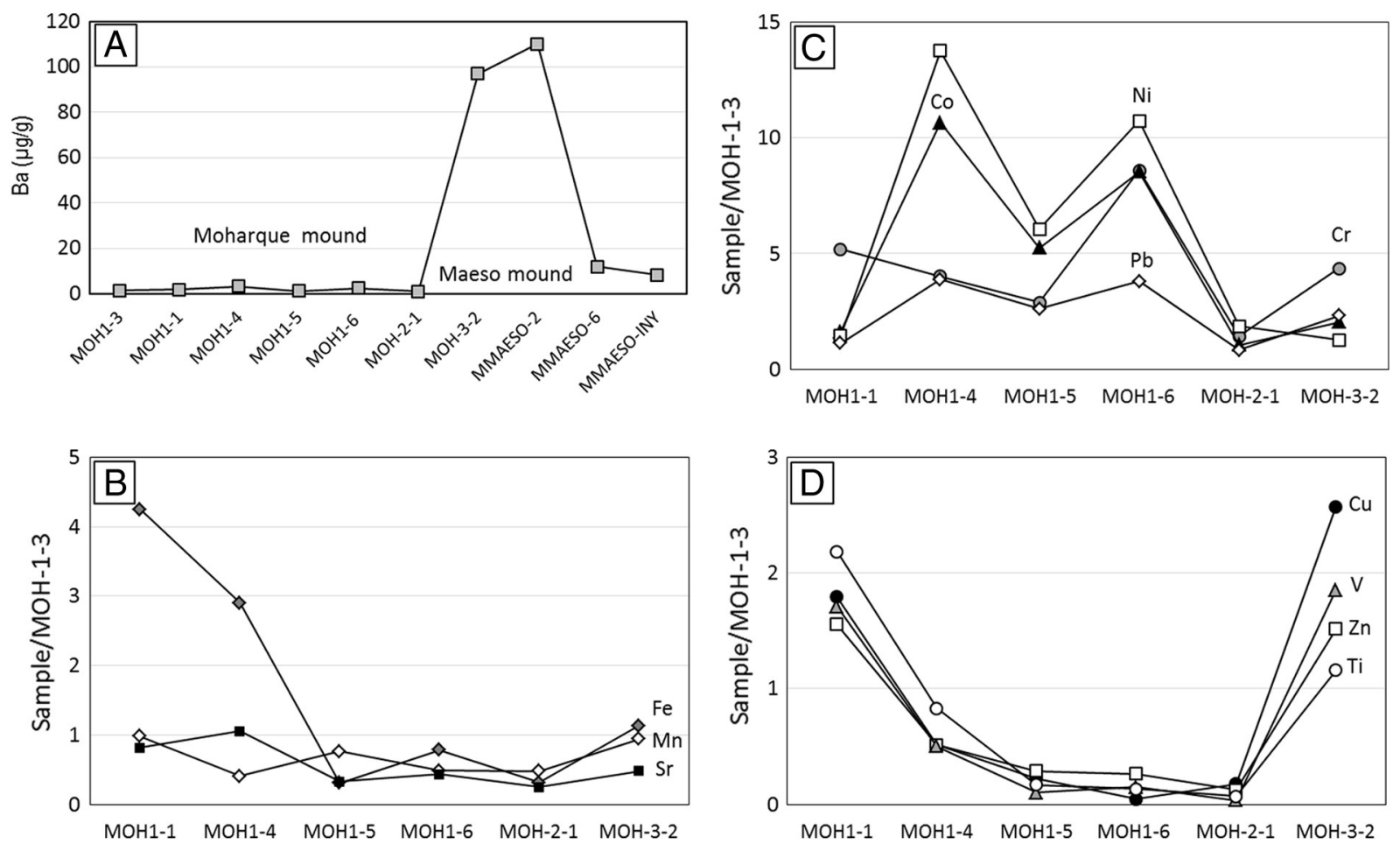

Fig. 16. Trace element geochemistry. A. Ba content (non-normalized) distribution in Moharque and Maeso mounds. B. Fe, Mn and Sr concentrations normalized to MOH-1-3. C. Ni, Co, $\mathrm{Pb}$ and $\mathrm{Cr}$ concentrations normalized to $\mathrm{MOH}-1-3$. D. $\mathrm{Cu}, \mathrm{Zn}, \mathrm{V}$ and $\mathrm{Pb}$ concentrations normalized to $\mathrm{MOH}-1-3$.

- Formation of dolomicroparite and dolosparite by aggrading neomorphism-induration/lithification

- Fracturing and small-scale folding up resulting in breccias-lithofacies F-2-2 and F-4

- $\mathrm{Co}(\mathrm{N})-\mathrm{Ni}(\mathrm{N}) \quad \square \mathrm{Co}(\mathrm{N})-\mathrm{Pb}(\mathrm{N})$
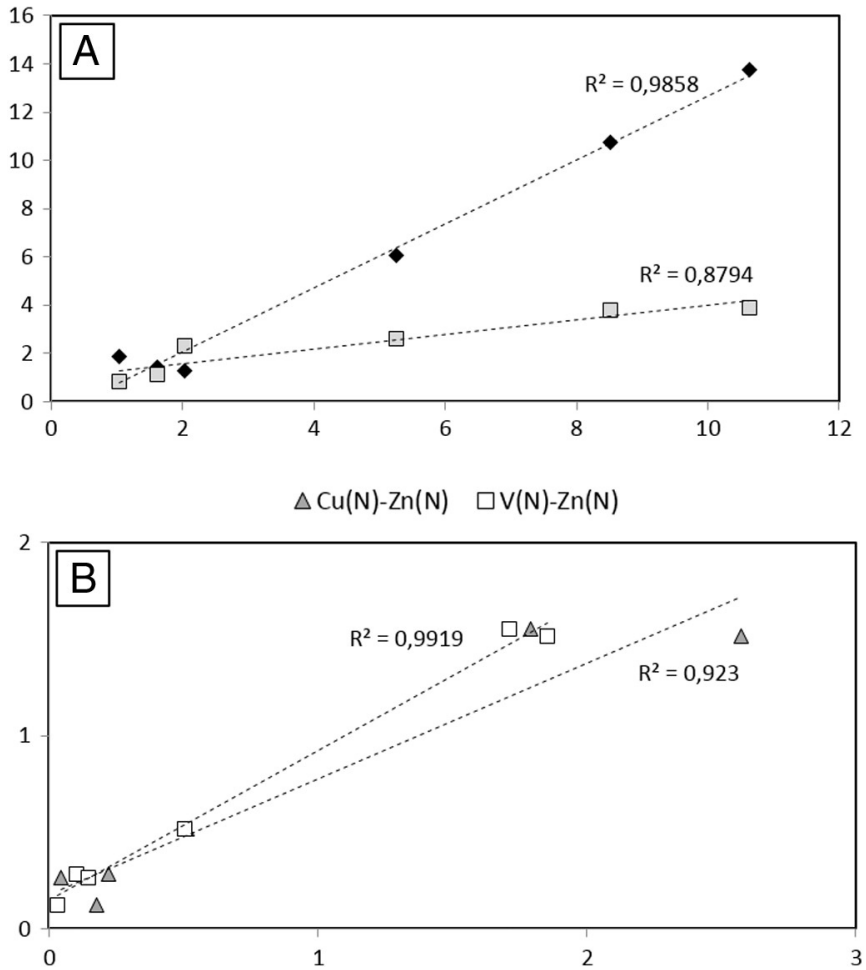

Fig. 17. Correlation coefficients $\left(\mathrm{R}^{2}\right)$ of trace elements. A. Bivariate plot of normalized $\mathrm{Ni}$ vs $\mathrm{Co}$ and $\mathrm{Ni}$ vs $\mathrm{Pb}$. B. Bivariate plot of normalized $\mathrm{Cu}$ vs $\mathrm{Zn}$ and $\mathrm{V}$ vs $\mathrm{Zn}$.
- Precipitation of opal C-T and microcrystalline quartz as both cementation and replacement of dolomicrite and/or dolosparite-lithofacies $\mathrm{F}-2-2$ and $\mathrm{F}-4$

- Precipitation of chalcedonite cement-lithofacies F-2-2 and F-4

- Replacement of dolomicrite and/or dolosparite mosaics by calcite-lithofacies F-4
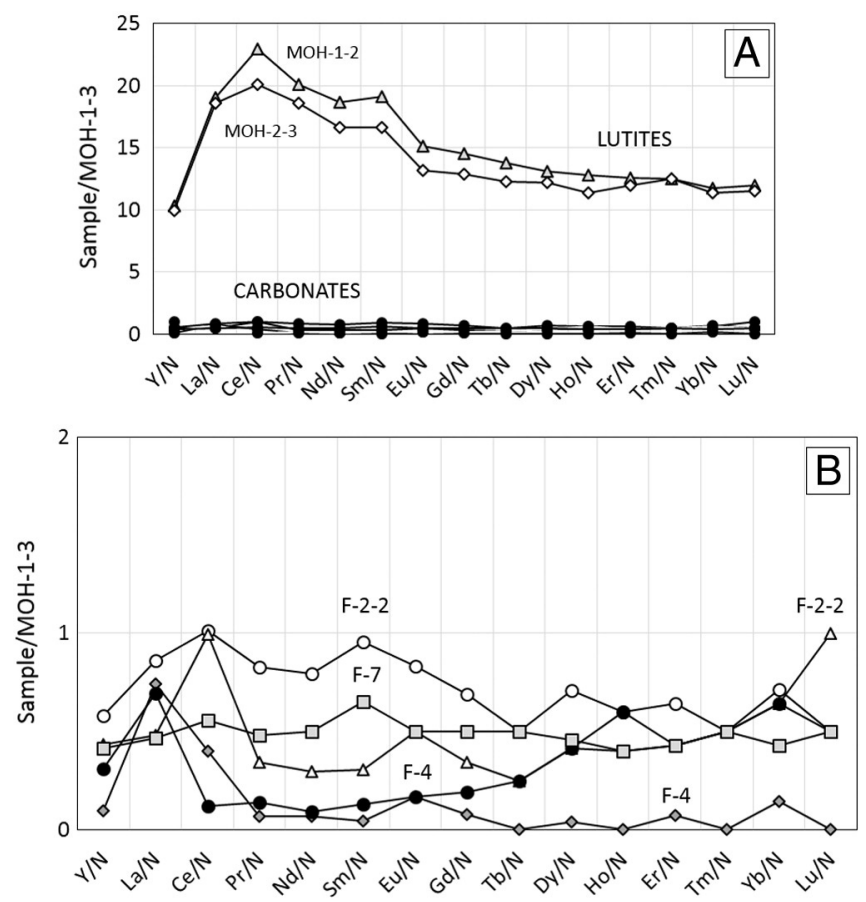

Fig. 18. REE geochemistry. A. REE content normalized to $\mathrm{MOH}-1-3$ in lutites and carbonates. B. Detail of REE distribution in carbonates. 

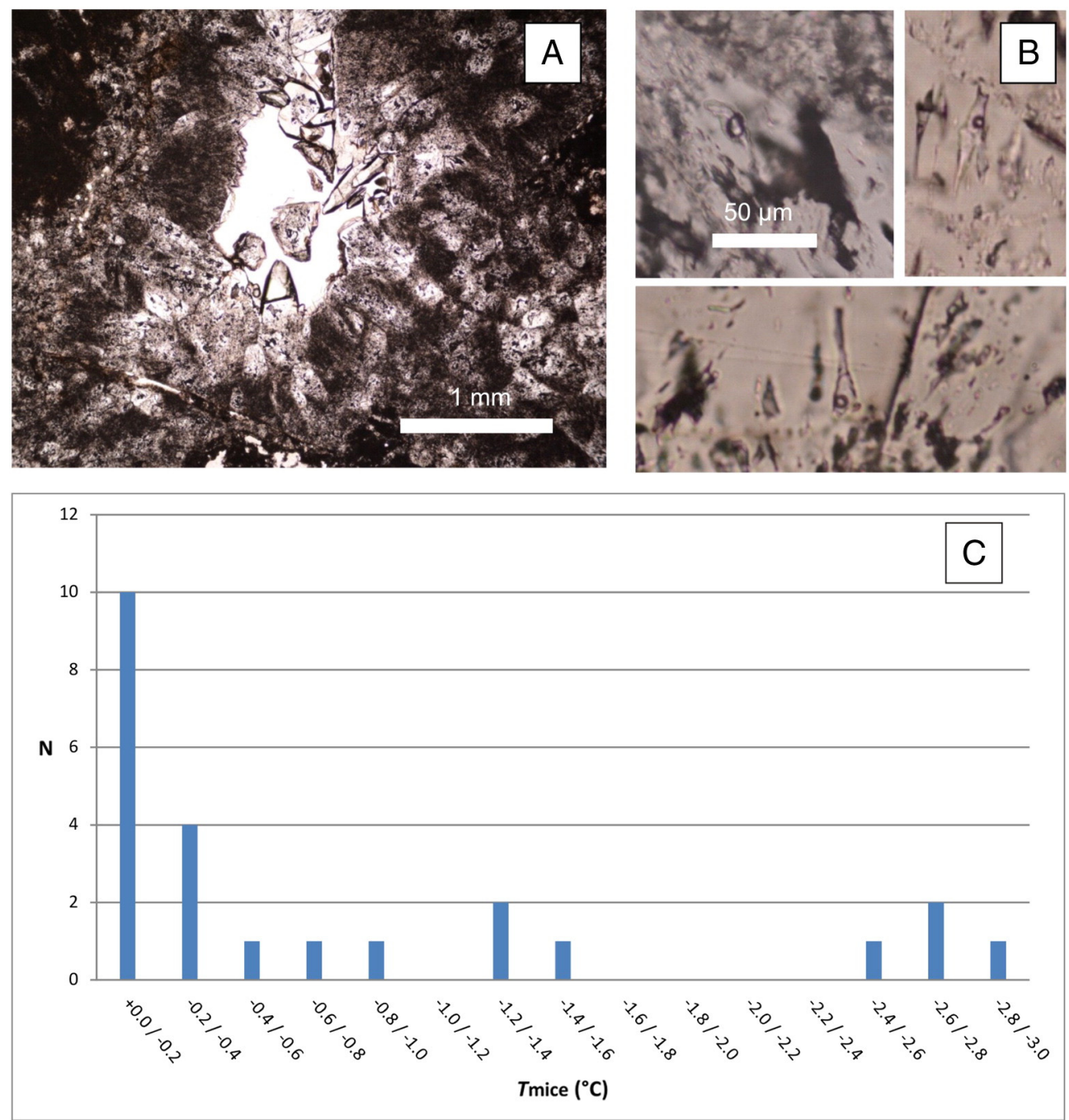

Fig. 19. Photomicrographs of non-ferroan calcite. A. Non-ferroan calcite limiting an open void in the breccias showing dog-tooth texture. Notice that crystals present a dirty nuclei and cleaner boundaries (PPL). B. Detail of a primary FI (encircled) (PPL). C. Histogram of fluid inclusion final melting of ice temperature ( $\mathrm{T}_{\mathrm{mice}}$ ). N: Number of measurements.

- C a I cite

ce mentationinopenvoids -lithofacies

F-5 and F-6. This

clearly indicates that cements of calcite mosaics postdate the dolomicrite masses and the dolosparite mosaics.

Asignificant increase of porosity occurred through processes dealing with the formation of lithofacies F-1 to F-4. Calcite cementation and probably the replacement of dolomite by calcite in telodiagenetic evolu-tionary stages of the carbonate mound is envisaged as a 'passive' process favoured by the large pore system.

\subsection{Carbonate mound growth model}

Field relations between the carbonate mounds and the host sedimentary sequence suggest that much of their growth took place in the shallow subsurface. This is supported by doming or convex-up geometry of the Moharque and $\mathrm{U}-1$ carbonate mounds resulting in inclined structure of the surrounding and overlying dolostone and marlstone beds (Figs. 4, 6). The resulting structure is similar to that described by Nelson et al. (2001) from spring deposits related to the Pleistocene Lake Tecopa, SE California. Nelson et al. (2001) described stratabound ledges within lake sediments, the effect being considered as a kind of 'inflation' of the sediments occurring at subsurface horizons as a result of fluids, i.e. thermal waters, flowing along fault conduits.

We interpret that the carbonate mounds currently exposed at the Las Minas Basin could grow as linear ridges due to the alter-ation, i.e. lithification and sedimentary fabric distortion with asso-ciated mineralogical and geochemical changes, of the carbonate sequence by thermal fluids moving lateral and vertical throughout the basinal faults (Fig. 20). Where groundwater reached the topog-raphy of the lake floor, carbonate deposits exhibiting sedimentary bedding and bioclastic and organic remains constituents were accumulated.

Several factors may have contributed to the rapid growth and inflation of the mounds. Water flow seeping throughout the hosting carbonate sequence could strength the dolomicrite and marlstone beds, firstly producing lithification and then creating overpressure conditions in a confined setting. Under these conditions, brecciation followed by mineral precipitation can reliably explain local volume increase. The process could be modelled similar to hydrofracturing (Phillips, 1972) and dilatational brecciation (Swennen et al., 2012) whereby fluids injected into the host rock produce an array of shear microfractures because of pressure differences between the low permeability host rock, i.e. dolomicrite, and the fluids circulating along the fault system. A detailed description of the hydrofracturing 
Table 6

Fluid inclusion measurements. FIA: Fluid inclusion assemblage (only when several cogenetic $\mathrm{Fl}$ appear together), L:V: Liquid to vapour ratio.

$T_{\text {mice }}$ : $\mathrm{Fin}$ a I m e I t ing of i c e te $\mathrm{m}$ - perature. $\mathrm{T}_{\mathrm{n}}$ : Nucleation temperature. $w \mathrm{t} \%$ ( $\mathrm{NaCl}-\mathrm{eq})$ : weight percent equivalent in $\mathrm{NaCl}$.

\begin{tabular}{|c|c|c|c|c|c|c|c|}
\hline Sample & FIA & $\mathrm{FI}$ & $\begin{array}{l}\text { Size } \\
(\mu \mathrm{m})\end{array}$ & $\mathrm{L}: \mathrm{V}$ & Tmice $\left({ }^{\circ} \mathrm{C}\right)$ & $\begin{array}{l}\text { Tn } \\
\left({ }^{\circ} \mathrm{C}\right)\end{array}$ & $\begin{array}{l}\text { Salinity \% w } \\
\text { (NaCl-eq) }\end{array}$ \\
\hline \multirow[t]{8}{*}{ MOH-1-13 } & & 1 & 20 & $95: 5$ & -2.8 & -42 & 4.65 \\
\hline & & 2 & 26 & $95: 5$ & -2.8 & -47 & 4.65 \\
\hline & & 3 & 22 & $95: 5$ & $-3.3 /-2.8$ & -49 & $4.65-5.41$ \\
\hline & & 4 & 10 & $95: 5$ & -0.2 & -43 & 0.35 \\
\hline & & 5 & 48 & $90: 10$ & -0.2 & -42 & 0.35 \\
\hline & & 6 & 30 & $90: 10$ & -0.4 & -41 & 0.71 \\
\hline & & 7 & 17 & $95: 5$ & -1.5 & -44 & 2.57 \\
\hline & & 8 & 15 & $60: 40$ & -0.4 & -41 & 0.71 \\
\hline \multirow[t]{3}{*}{ JABA-OB } & & 1 & 22 & $90: 10$ & 0 & -39 & 0.00 \\
\hline & & 2 & 8 & $95: 5$ & -0.2 & & 0.35 \\
\hline & & 3 & 11 & $90: 10$ & 0 & -38 & 0.00 \\
\hline \multirow[t]{7}{*}{ TOPMOH-5 } & 1 & 1 & 18 & $85: 15$ & 0 & -40 & 0.00 \\
\hline & 1 & 2 & 14 & $85: 15$ & 0 & & 0.00 \\
\hline & 1 & 3 & 18 & $90: 10$ & $-0.2 / 0$ & -43 & $0.00-0.35$ \\
\hline & 1 & 4 & 12 & $90: 10$ & -0.2 & -42 & 0.35 \\
\hline & & 5 & 4 & $95: 5$ & $-1.5 /-1.3$ & -43 & $2.24-2.57$ \\
\hline & 2 & 6 & 6 & $80: 20$ & -0.3 & NO & 0.53 \\
\hline & 2 & 7 & 9 & $70: 30$ & -0.8 & NO & 1.40 \\
\hline \multirow[t]{6}{*}{ MOH-2-1 } & & 1 & 10 & $95: 5$ & -0.9 & -42 & 1.57 \\
\hline & & 2 & 6 & $95: 5$ & $-1.4 /-1.3$ & -34 & $2.24-2.41$ \\
\hline & & 3 & 7 & $85: 15$ & -0.1 & -35 & 0.18 \\
\hline & & 4 & 8 & $90: 10$ & -0.3 & -39 & 0.53 \\
\hline & & 5 & 8 & $90: 10$ & -0.5 & -40 & 0.88 \\
\hline & & 6 & 16 & $90: 10$ & $-2.6 /-2.5$ & -44 & $4.18-4.34$ \\
\hline
\end{tabular}

mechanisms was provided by Swennen et al. (2012) by discussing dolomitization processes related to a main fault system in northern Spain. Several aspects dealing with cyclicity of fluids movement, ef-fect of fluid expulsion on changes in pore fluid pressure, cooling of the ascent of hot fluids leading to carbonate dissolution and/or fragmentation (Giles and de Boer, 1990; Davies, 2004), etcetera, described for the formation of hydrothermal dolomites (Vandeginste et al., 2005; Swennen et al., 2012; Morrow, 2014) c o u I d b e t o a some extent applied to the growth of the carbonate mounds of the Las Minas Basin.

The ascending fluid flo w pat ter $n$ with in man y parts ofthemound is clearly indicated by the vertically banded carbonate (Fig. 4C). This out-standing feature occurs usually associated with the large pore space characteristic of the box-work fabric. Morrow (2014) described the latter fabric as a dissolutional, rather than dilational, evidence for the creation of pore space in hydrothermal dolomites. Being aware of the distinct geological setting, we consider that the boxwork-like fabric ob-served in the carbonate mounds of Las Minas can be concealed with the dilational and breccias-forming processes proposed for the formation of these deposits.

\subsection{Fluid geochemistry and mineral precipitation}

Properties as temperature, enthalpy, and composition of the fluids contributing to the formation of the carbonate mounds can be deduced from the mineralogy of the precipitates and the geochemistry of carbonate and fluid inclusions. Again, distinction between the mounds interpreted as growing at subsurface (Moharque, U-1, U-2 mounds) and the Maeso carbonate mound, interpreted mostly as subaqueous deposits, is substantial. In the former case dolomite represents the altered host rock and the new mineral phases are calcite and silica; in the latter deposits cal-cite and dolomite are present with negligible amount of silica. It is noted that no aragonite was identified in any of the collected sam-ples, which is in agreement with that observed in many spring deposits though reasons for prevalence of calcite against aragonite remains unclear (Pentecost et al., 2003; Jones and Renaut, 2010).

Silica precipitates can be used as an indicator of relatively hot water flowing throughout the basin faults (Jones and Renaut, 2010; Renaut et al., 2002). An alternative view of alkaline waters favouring precipitation of silica in the lake can be ruled out since it would be incompatible with gypsum precipitation (Ortí et al., 2014). Under hydrothermal conditions, silica supersaturated water inducing precipitation of quartz and/or opal is reached where the fluid approaches the surface. In the studied carbonate mounds supersaturation was probably favoured by brecciation of the lithified host rock; a combined effect of decompression and decrease of temperature in the brecciated carbonate could en-hance silica precipitation even though the fluid was not highly saturated in silica (Williams and Crerar, 1985; Knauth, 1992; Renaut et al., 2002).

The carbonate host rock provided high alkaline conditions which together hydrothermal gradients favoured precipitation of opal CT and its further transformation into quartz. The presence of sulphates in underlying horizons of the basin sedimentary sequence could ac-count for the formation of length-slow chalcedonite.

The composition and temperature of the fluids that formed the carbonate mounds of Las Minas are uncertain. Insight from fluid inclusions was only searched in big calcite crystals that very probably represent late stages, so relative cooling conditions, of mineral precipitation. Unfortunately no clear evidence from either recrystallized dolomite or quartz regarding temperature and/or composition of fluids could be obtained.

\subsection{Concluding remarks}

The carbonate mounds studied in the Las Minas Basin are mostly composed of folded and/or brecciated dolomite beds similar to those forming the sedimentary sequences in which the mounds occur interstratified. This type of internal organization and fabric is clearly distinctive from the carbonate mounds usually described in the geological literature as they commonly show some kind of skeletal and/or biogenic structure, which is the case of tufa, travertine, mud-mound carbonates, and others.

Moreover, the studied carbonate mound deposits display aggrading neomorphism of dolomite, partial replacement of dolomite by calcite, calcite cementation, and extensive silicification, locally resulting in boxwork fabric. These features point to predominance of physicochemical and mechanical processes in building up the mounds. Table 7 summarizes the specific features shown by the mounds and their comparison to other types of carbonate mounds described in liter-ature. Lack of skeletal and/or organic remains within the mounds, ex-cept for the Maeso one, supports the specificity of their origin and development.

It is concluded that formation of the carbonate mounds was related to local artesian seepage thermal water flows of moderate to relative high temperatures. This interpretation is supported by the distribution of carbonate lithofacies within the mounds as well as by the sequential arrangement of mineral precipitates. Pressure differences between the low permeability host rock and the circulating fluids accounted for dilational fracturing and brecciation of the host sediment packages, which combined with precipitation of new carbonate and silica mineral phases.

\section{Acknowledgments}

We are especially thankful to our colleagues and friends Adriana Bellanca and Rodolfo Neri with whom we shared nice field work campaigns and exchanged sound scientific discussions. The authors 

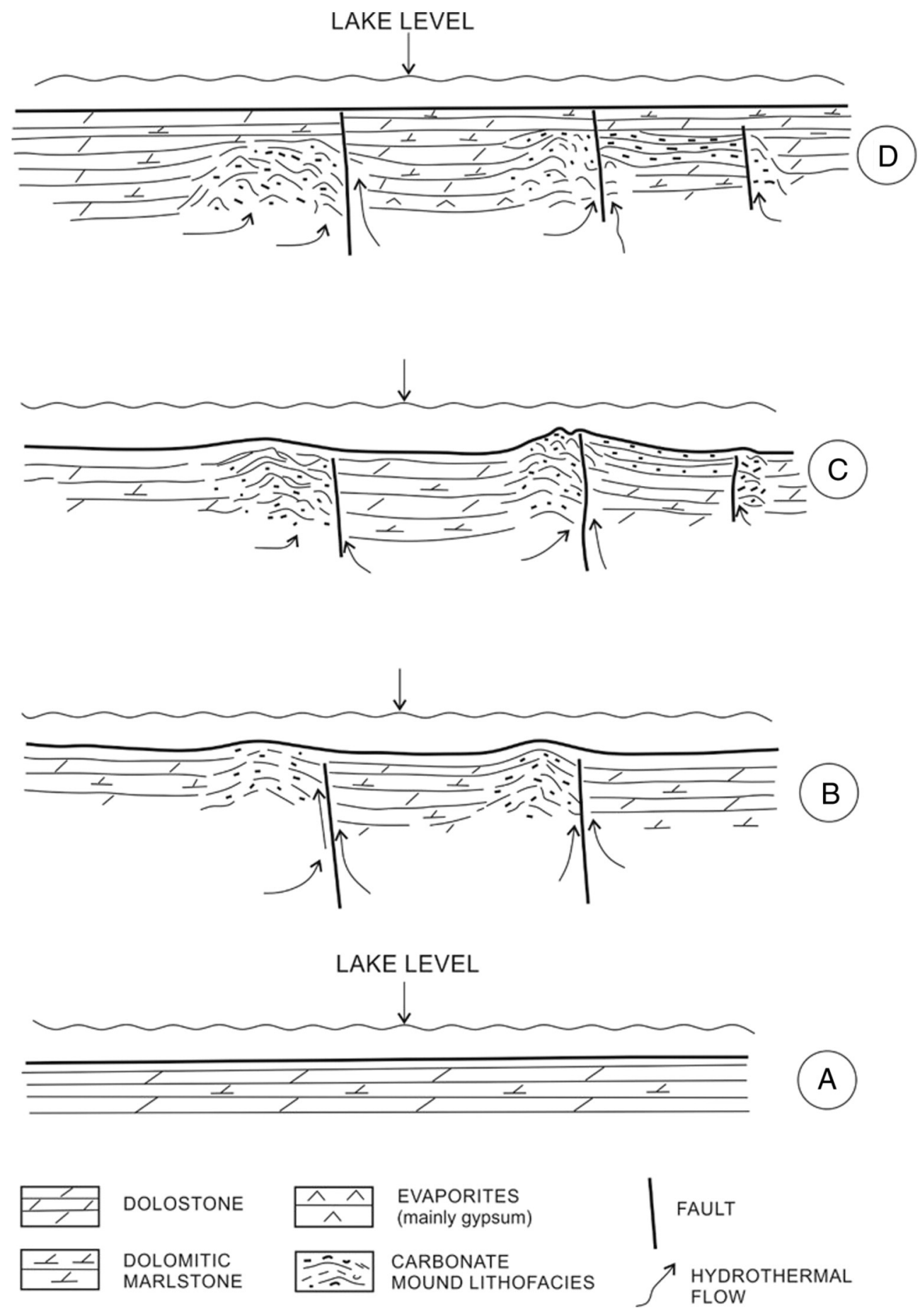

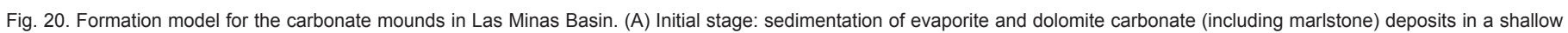

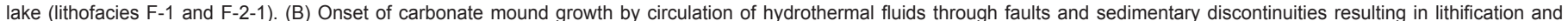

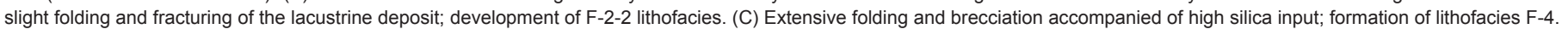

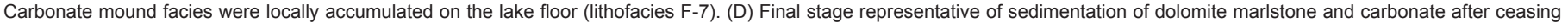
hydrothermal water seepage.

thank also María José Huertas (Universidad Complutense Madrid), Federico Ortí, Laura Rosell, Lluis Gibert, Elisabet Playà (Universidad de Barcelona), Jean-Marie Rouchy (Muséum National d'Histoire Naturelle de Paris, CNRS), David Gómez-Gras (Universitat Autonoma de Barcelona), Pedro Alfaro (University of Alicante), Carlos Rossi (UC Madrid) and Miguel A. Rodríguez-Pascua (IGME) for encouraging discussions in both the field and the cabinet. The authors thank Dr. Brian Jones, Editor-in-Chief of Sedimentary Geology and two anonymous reviewers for their very encouraging and helpful comments that greatly improved an earlier version of the manuscript. Agustín Blanco is acknowledged for technical support drawing many illustrations shown in the paper. Pedro Lozano and Marian Barajas assisted in the preparation of thin sections and material dealing with fluid inclusion analysis. The scientific work is included with-in the research activities of the Research groups C-144 (UAM, Geomaterials and Geological Processes) and UCM-910607. 
Table 7

Comparison of sedimentary features and formation processes of carbonate

\begin{tabular}{|c|c|c|c|c|c|}
\hline & $\begin{array}{l}\text { Carbonate build ups } \\
\text { (skeletal to mud mounds) } \\
(1,2)\end{array}$ & Seep mounds $(3,4)$ & Mound springs $(5,6)$ & $\begin{array}{l}\text { Hot-water spring mounds } \\
(7,8)\end{array}$ & $\begin{array}{l}\text { Seepage mounds } \\
\text { (this study) }\end{array}$ \\
\hline Shape & $\begin{array}{l}\text { Commonly dome-shaped, } \\
\text { pinnacles, rarely } \\
\text { flat-shaped }\end{array}$ & Dome-shaped, pinnacles & $\begin{array}{l}\text { Dome-shaped, } \\
\text { pinnacles, rimstone } \\
\text { dam-and-pool } \\
\text { architecture }\end{array}$ & $\begin{array}{l}\text { Dome-shaped, rimstone } \\
\text { dam-and-pool architecture }\end{array}$ & Dome-shaped \\
\hline $\begin{array}{l}\text { Structure, } \\
\text { fabric \& } \\
\text { dominant } \\
\text { mineralogy }\end{array}$ & $\begin{array}{l}\text { Organic framework, } \\
\text { massive (carbonate } \\
\text { mud-mounds) } \\
\text { Framestone }^{\mathrm{a}} \text {, boundstone }{ }^{\mathrm{a}} \text {, } \\
\text { bafflestone }^{\mathrm{a}} \\
\mathrm{CaCO}_{3} \text { (low and high } \\
\mathrm{Mg-calcite} \text { and/or }^{\text {aragonite) }}\end{array}$ & $\begin{array}{l}\text { Massive to clotted fabric, } \\
\text { microbial build-up locally } \\
\text { including invertebrate fossils } \\
\text { Bindstone }^{\mathrm{a}} \text {, bafflestone } \\
\mathrm{CaCO}_{3} \text { (high Mg-calcite and/or } \\
\text { aragonite), dolomite, methane, } \\
\text { clays }\end{array}$ & $\begin{array}{l}\text { In situ vegetation growth } \\
\text { (cool-water tufa } \\
\text { facies)-interfingering } \\
\text { clastic sediment } \\
\text { Boundstone }^{\mathrm{a}} \text {, bindstone } \\
\mathrm{CaCO}_{3} \text { (low and high } \\
\text { Mg-calcite, aragonite) }\end{array}$ & $\begin{array}{l}\text { Travertine-like (microbial } \\
\text { build-up) associated with in } \\
\text { situ vegetation growth } \\
\text { Bindstone }^{\mathrm{a}} \text {, boundstone } \\
\mathrm{CaCO}_{3} \text { (low and high } \\
\text { Mg-calcite, aragonite) and } \\
\text { chert (dominant in } \\
\text { hyperthermal springs) }\end{array}$ & $\begin{array}{l}\text { Breccias-like structure } \\
\text { combining strongly folded and } \\
\text { fractured lithified beds } \\
\text { Local box-work fabric } \\
\text { Low-Mg calcite, dolomite and } \\
\text { chert }\end{array}$ \\
\hline $\begin{array}{l}\text { Main } \\
\quad \text { building-up } \\
\text { processes }\end{array}$ & $\begin{array}{l}\text { Formation of resistant } \\
\text { framework dealing with } \\
\text { organic build up, } \\
\text { accumulation of carbonate } \\
\text { mud by trapping and } \\
\text { baffling }\end{array}$ & $\begin{array}{l}\text { Fluid seepage along } \\
\text { synsedimentary faults supplying } \\
\text { alkaline thermogenic water } \\
\text { Microbially-mediated carbonate } \\
\text { precipitation }\end{array}$ & $\begin{array}{l}\text { Subaerial to subaqueous } \\
\text { groundwater discharge. } \\
\mathrm{CaCO}_{3} \\
\text { encrustation/precipitation } \\
\text { within and around plants } \\
\text { related to } \mathrm{CO}_{2} \text { degassing }\end{array}$ & $\begin{array}{l}\text { Thermal waters discharge } \\
\text { along relatively deep fissures. } \\
\text { Pool and mound precipitation } \\
\text { around spring vents. Variation } \\
\text { of deposits with distance to } \\
\text { spring }\end{array}$ & $\begin{array}{l}\text { Thermal groundwater } \\
\text { discharge along faults resulting } \\
\text { in fracturing and brecciation of } \\
\text { subsurface strata pushed up by } \\
\text { overpressure water }\end{array}$ \\
\hline $\begin{array}{l}\text { Depositional } \\
\text { environment }\end{array}$ & $\begin{array}{l}\text { Usually marine carbonate } \\
\text { platforms, more rarely in } \\
\text { lakes }\end{array}$ & $\begin{array}{l}\text { Usually deep-water marine } \\
\text { environments (shelf, slope) } \\
\text { Occasional occurrences in alkaline } \\
\text { lakes }\end{array}$ & $\begin{array}{l}\text { Freshwater spring related } \\
\text { environments } \\
\text { Subaerial, more rarely } \\
\text { below lake water level }\end{array}$ & $\begin{array}{l}\text { Fresh to saline water, thermal } \\
\text { spring-related } \\
\text { environments } \\
\text { Subaerial, more rarely in } \\
\text { shallow lake water }\end{array}$ & $\begin{array}{l}\text { Mound structures developed } \\
\text { in a lake sedimentary sequence } \\
\text { altered in depth } \\
\text { Local association with springs }\end{array}$ \\
\hline
\end{tabular}

References for carbonate mound types: (1) Wilson, 1975; (2) Tucker and Wright, 1990; (3) Schlager (2003); ( 4 ) Conti and Fontana (2005); ( 5 ) Linares et al. (2010); ( 6 ) Keppel et al.(2011); ( 7 ) Pentecost et al. (2003); ( 8 ) Jones and Renaut (2010).

a Embry and Klovan (1971) terminology for carbonate textural types.

\section{References}

Bellanca, A., Calvo, J.P., Censi, P., Elizaga, E., Neri, R., 1989. Evolution of diatomitecarbonate lacustrine cycles of Miocene age, Southeastern Spain: petrology and isotope geochemistry. Journal of Sedimentary Petrology 59, 45-52.

Bellon, H., Bizon, G., Calvo, J.P., Elizaga, E., Gaudant, J., López, N., 1981. Le volcan du Cerrodel Monagrillo (Prov. de Murcia): Âge absolu et correlation avec les sediments néogènes du Bassin d'Hellín (Espagne). Comptes Rendus de l'Académie des Sciences Paris, 2 sér 292, 1035-1038.

Bodnar, R.J., 1993. Revised equation and table for determining the freezing point depression of $\mathrm{H}_{2} \mathrm{O}-\mathrm{NaCl}$ solutions. Geochimica et Cosmochimica Acta 57, 683-684.

Brasier, A.T., 2011. Searching for travertines, calcretes and speleothems in deep time: processes, appearances, predictions and the impact of plants. Earth-Science Reviews 104, 213-239.

Calvo, J.P., Elízaga, E., 1994. In: Gierlowski-Kordesch, E., Kelts, K. (Eds.), The Cenajo and LasMinas-Camarillas basins (Miocene), southeastern SpainGlobal Geological Record of Lake Basins 1. Cambridge Univ. Press, pp. 319-324.

Calvo, J.P., Gómez-Gras, D., Alonso-Zarza, A.M., Jiménez, S., 2000. Architecture of a type carbonate lake margin and its relation to fluvially dominated deltas, Las Minas Basin, Upper Miocene, Spain. Journal of Sedimentary Research 70, 240-254.

Calvo, J.P., Pozo, M., Jones, B.F., 1995. Preliminary report of seepage mound

occurrences Spain. inComparison with carbonate mounds from the Amargosa Desert,

western USA. Geogaceta 18, 67-70.

Chafetz, H.S., Guidry, S.A., 2003. Deposition and diagenesis of Mammoth Hot Springs travertine, Yellowstone National Park, Wyoming, U.S.A. Canadian Journal of Earth Sciences 40, 1515-1529.

Chung, F.H., 1974. Quantitative interpretation of X-ray diffraction patterns of mixtures. II. Adiabatic principle of X-ray diffraction analysis of mixtures. Journal of Applied Crys-tallography $7,526-531$.

Conti, S., Fontana, D., 2005. Anatomy of seep carbonates: ancient examples from the Miocene of the northern Apennines (Italy). Palaeogeography, Palaeoclimatology, Palaeoecology 227, 156-175.

Davies, G.R., 2004. Hydrothermal (thermobaric) dolomitization: rock fabric and organic petrology support for emplacement under conditions of thermal transients, shear stress, high pore fluid pressure with abrupt pressure transients, hydrofracturing, episodic rapid fluid flow, and instantaneous cementation by saddle dolomite. In: Davies, G.R., Packard, J., McAuley, R. (Eds.), Dolomite Seminar and Core Conference. Canadian Society of Petroleum Geologists, Calgary.

Elízaga, E., 1994. Análisis de facies sedimentarias y petrología de los depósitos lacustres de edad Neógeno superior de la Zona Prebélica, Albacete, España. Instituto de Estudios Albacetenses, Albacete, Spain (216 pp.).

Embry, A.F., Klovan, J.E., 1971. A Late Devonian reef tract on northeastern Banks

Islands,Northwest territories. Bulletin of Canadian Petroleum Geology 19, 730-781.

Fouke, B.W., 2011. Hot-spring System Geobiology: abiotic and biotic influences on travertine formation at Mammoth Hot Springs, Yellowstone National Park, USA. Sedimen-tology 58, 170-219.
Fouke, B.W., Farmer, J.D., Des Marais, D.J., Pratt, L., Sturchio, N.C., Burns, P.C., Discipulo, M.K., 2000. Depositional facies and aqueous-solid geochemistry of travertinedepositing hot spring (Angel terrace, Mammouth hot springs, Yellowstone National Park, USA). Journal of Sedimentary Research 70, 565-585.

Fúster, J.M., Gastesi, P., Sagredo, J., Fermoso, J.L., 1967. Las rocas lamproíticas del sudeste de España. Estudios Geológicos 22, 35-69.

Giles, M.R., de Boer, R.B., 1990. Origin and significance of redistributional secondary porosity. Marine and Petroleum Geology 7, 379-397.

Goldsmith, J.R., Graf, D., Heard, H.C., 1961. Lattice constants of the calcium-

magceesianates. American Mineralogist 46, 453-457.

Goldsmith, J.R., Graf, D.L., 1958. Relation between lattice constants and composition of

the Ca-Mg carbonates. American Mineralogist 43, 84-101.

Goldstein, R.H., Reynolds, T.J., 1994. Systematics of fluid inclusions in diagenetic minerals. SEPM Short Course 31 (192 pp.).

Gonfiantini, R., 1986. Environmental isotopes in lake studies. In: Fritz, P., Fontes, J.Ch. (Eds.), Handbook of Environmental Isotope Geochemistry, 2. Elsevier, Amsterdam, pp. 113-168.

Jones, B., Renaut, R.W., 2010. In: Alonso-Zarza, A.M., Tanner (Eds.), Calcareous spring

- posits in continental settingsDevelopm. in Sedimentology 61. Elsevier, Amsterdam, pp. 177-224.

Keppel, H.N., Clarke, J.D.A., Halihan, T., Love, A.J., Werner, A.D., 2011. Mound springs in the arid Lake Eyre South region of South Australia: a new depositional tufa model. Sedimentary Geology 240, 55-70.

Knauth, L.P., 1992. Origin and diagenesis of cherts: an isotopic perspective. In: Clauer,

N., Chauthun, S. (Eds.), Isotopic Signatures and Sedimentary RecordsLecture Notes in Earth Sciences 43. Springer, pp. 123-152.

Linares, R., Rosell, J., Roque, C., Gutierrez, F., 2010. Origin and evolution of tufa mounds related to artesian karstic springs in Isona area (Pyrenees, NE Spain). Geodinamica Acta $23,129-150$.

Lindtke, J., Ziegenbalg, S.B., Bunner, B., Rouchy, J.M., Pierre, C., Peckmann, J., 2011. Authigenesis of native sulphur and dolomite in a lacustrine evaporitic setting (Hellín basin, Late Miocene, SE Spain). Geological Magazine 148, 655-669.

Lumsden, D.N., 1979. Discrepancy between thin section and X-ray estimates of dolomite in limestone. Journal of Sedimentary Petrology 49, 429-436.

Miller, J., 1988. Microscopical techniques. I. Slices, slides, stains and peels. In: Tucker,

M.E.(Ed.), Techniques in Sedimentology. Blackwell Sci, Oxford, pp. 86-107.

Minissale, A., Kerrick, D.M., Magro, G., Murrell, M.T., Paladini, M., Rihs, S., Sturchio,

N.C.,Tassi, F., Vaselli, O., 2002. Geochemistry of Quaternary Travertines in the Region North of Rome (Italy): Structural, Hydrologic and Paleoclimatic Implications. Earth Panet.Sci. letters 203 pp. 709-728.

Morrow, D.W., 2014. Zebra and boxwork fabrics in hydrothermal dolomites of northern Canada: indicators for dilational fracturing, dissolution or in situ replacement? Sedimentology 61, 915-951.

Nelson,S.T.,Karlsson,H.R.,Paces,J.B.,Tingey,D.G., Paleohydrologic

Ward,S.,Peters,M.T.,2001.record of spring deposits in and around Pleistocene

pluvial Lake Tecopa, southeastern California. Geological Society of America Bulletin $113,659-670$. 


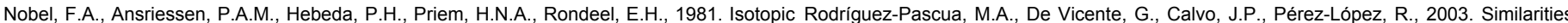
dating of the postalpine neogene volcanism in the Betic cordilleras, Southern Spain. Geologie en Mijnbouw 60, 209-214.

Ortí, F., Rosell, L., Gibert, L., Moragas, M., Playà, E., Inglès, M., Rouchy, J.M., Calvo,

J.P.,Gimeno, D., 2014. Evaporite sedimentation in a tectonically active basin: the lacusrine Las Minas Gypsum unit (Late Tortonian, SE Spain). Sedimentary Geology 311, 17-42.

Pedley, H.M., 2009. Tufas and travertines of the Mediterranean region: a testing ground for freshwater carbonate concepts and developments. Sedimentology 56, 221-246.

Pentecost, A., 2005. Travertine. Springer, Berlin.

Pentecost, A., Jones, B., Renaut, R.W., 2003. What is a hot spring? Canadian Journal of Earth Sciences 40, 1443-1446.

Phillips, W.J., 1972. Hydraulic fracturing and mineralization. Journal of the Geological

So- ciety of London 128, 337-359.

Playà, E., Gimeno, D., 2006. Evaporite deposition and coeval volcanism in the Fortuna Basin (Neogene, Murcia, Spain). Sedimentary Geology 188-189, 205-219.

Renaut, R.W., Jones, B., 2000. Microbial precipitates around continental hot springs and geysers. In: Riding, R.E., Awramik, S.M. (Eds.), Microbial Sediments. Springer, Berlin, pp. 187-195.

Renaut, R.W., Jones, B., 2003. Sedimentology of hot spring systems. Canadian

Journal Earth ofSciences 40, 1439-1738.

between recent seismic activity and paleoseismites during the late Miocene in the external Betic Chain (Spain): relationship by 'b' value and the fractal dimension. Journal of Structural Geology 25, 749-763.

Sanz de Galdeano, C., Vera, J.A., 1992. Stratigraphic record and palaeogeographical context of the Neogene basins in the Betic Cordillera, Spain. Basin Research 4, 21-36.

Schlager, W., 2003. Benthic carbonate factories of the Phanerozoic. International

Journalof Earth Sciences 92, 445-464.

Sherperd, T.J., Rankin, A.H., Alderton, D.H.M. 1985. A practical guide to fluid inclusion studies. Ed. Blakie, Glasgow and London, (239 pp.)

Swennen, R., Dewit, J., Fierens, E., Muchez, P., Shah, M., Nader, F., Hunt, D., 2012.

Multipledolomitization events along the Pozalagua Fault (Pozalagua Quarry,

Basque-Cantabrian Basin, Northern Spain). Sedimentology 59, 1345-1374.

Tucker, M.E., Wright, V.P., 1990. Carbonate Sedimentology. Blackwell Science, Oxford.

Vandeginste, V., Swennen, R., Gleeson, S.A., Ellam, R.M., Osadetz, K., Roure, F., 2005

Zebradolomitization as a result of focused fluid flow in the Rocky Mountain Fold and

Thrust Belt, Canada. Sedimentology 52, 1067-1095.

Van der Beek, P.A., Cloeting, G., 1992. Lithospheric flexure and the tectonic evolution of the Betic Cordilleras (SE Spain). Tectonophysics 203, 325-344.

Williams, L.A., Crerar, D.A., 1985. Silica diagenesis, II. General mechanisms. Journal of Sedimentary Petrology 55, 312-321.

Renaut, R.W., Morley, C.K., Jones, B., 2002. In: Renaut, R.W., Ashley, G.M. (Eds.), Fossil hot-Wilson, J.L., 1975. Carbonate Facies in Geologic History. Springer Verlag, spring travertine in the Turkana Basin, northern Kenya: structure, facies, and genesisSedimentation in Continental Rifts 73. SEPM Special Publication, pp.

123-141. Riding, R., 2002. Structure and composition of organic reefs and carbonate mud mounds:concepts and categories. Earth-Science Reviews 58, 163-231. 